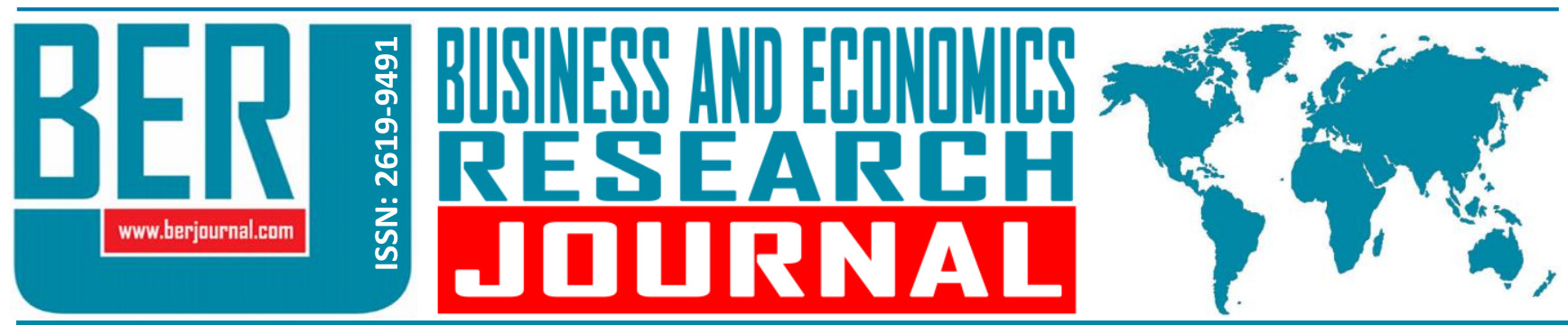

Business and Economics Research Journal Vol. 11, No. 4, 2020, pp. 969-988 doi: 10.20409/berj.2020.293

\title{
Türkiye'de Kredi Büyümesinin Belirleyicilerinin Zamanla Değişen Nedensellik Testiyle Analizi
}

\author{
Taner Sekmen ${ }^{\mathrm{a}}$, Seher Gulsah Topuz ${ }^{\mathrm{b}}$
}

Öz: Son yıllarda kredi büyümesi finansal sistemin gelişimi ve iktisadi büyümenin ana itici gücü olmasına rağmen kredi büyümesini etkileyen faktörlerin yeterince anlaşıldığı söylenemez. Bu çalışmada Türkiye'de finansal sistemin önemli bir parçasını oluşturan kredi büyümesini hangi iktisadi faktörlerin belirlediği incelenmektedir. 2006Q1-2019Q4 dönemi için yapılan ekonometrik tahminler Toda ve Yamamoto (1995) ve Hacker ve Hatemi-J (2006) nedensellik testlerine dayanmaktadır. Ancak bizim yaklaşımımız zamanla değişen nedenselliği hesaba katmaktadır. Kredi büyümesinin belirleyicileri olarak bankacılık sektörüne iliş̧in değişkenlerin yanı sıra ülkenin makro iktisadi ve para politikası koşulları ile dış talep ve küresel likidite koşullarını temsil eden değişkenler incelenmektedir. Makro iktisadi değişkenlerden GSYH büyüme oranı ve enflasyon oranının kredi büyümesini yönlendirici olduğu fakat kamu borcundan kredilere doğru ise daha seyrek nedensellik ilişkisi olduğu tespit edilmektedir. Para politikası ile ilişkili olarak ise para arzından kredi büyümesine doğru nedensellik, TCMB faiz oranlarına göre daha belirsizdir. Benzer şekilde, dış talep ve küresel likidite koşullarını temsil eden $A B D$ federal fon oranı, sermaye girişi ve döviz kuru değişkenlerinden kredi arzına doğru da dönemsel nedensellik ilişkilerine rastlanmaktadır. Bu bulgular kredi büyümesi ile onun belirleyicileri arasındaki nedensellik ilişkilerinin zamana bağlı olarak değişkenlik gösterdiğini açıkça göstermektedir. Dolayısıyla kredi büyümesinin istikrarına yönelik politikaların dinamik bir şekilde tasarlanması gerektirdiği ortaya konulmaktadır.

\section{Analysis of Determinants of Credit Growth with Time- Varying Causality Test in Turkey}

Abstract: Although credit growth has been the main driver of financial development and economic growth in recent years, the factors affecting credit growth cannot be said to be sufficiently understood. This study examines which economic factors determine credit growth, which is an important part of the financial system in Turkey. Econometric estimates for the 2006Q1-2019Q4 period are based on Toda and Yamamoto (1995) and Hacker and Hatemi-J (2006) causality tests. However, our approach takes into account the time-varying causality. In addition to the variables related to the banking sector, the variables representing the country's macro-economic and monetary policy conditions, and foreign demand and global liquidity conditions are examined as determinants of credit growth. It is determined that GDP growth rate and inflation rate, which are among macroeconomic variables, lead credit growth, but less frequently causality relationship is from public debt to credit growth. Regarding monetary policy, causality from money supply to credit growth is more uncertain than Central Bank of the Republic of Turkey (CBRT) interest rates. Similarly, periodic causality relationships are observed from the variables of US federal funds, capital inflows, and exchange rates, which represent foreign demand and global liquidity conditions, to credit growth. These findings clearly show that causal relationships between credit growth and its determinants are time-varying. Therefore, it is revealed that policies towards the stability of credit growth require a dynamic design.

Anahtar Sözcükler: Kredi Büyümesi, Finansal Sistem, Bankacılık Sektörü, Zamanla Değişen Nedensellik, Türkiye

JEL: C13, E40, E51

Gelis : 16 Mayıs 2020

Düzeltme : 22 Haziran 2020

Kabul : 04 Ağustos 2020

Tür

: Araştırma

Keywords: Credit Growth, Financial System, Banking Sector, Time Varying Causality, Turkey

JEL: C13, E40, E51

Received : 16 May 2020

Revised : 22 June 2020

Accepted : 04 August 2020

Type : Research

a Asst. Prof., PhD., Eskisehir Osmangazi University, Faculty of Economics and Administrative Sciences, Department of Economics, Eskisehir, Turkiye, tsekmen@ogu.edu.tr (ORCID ID: 0000-0002-0363-3765)

b Asst. Prof., PhD., Eskisehir Osmangazi University, Faculty of Economics and Administrative Sciences, Department of Economics, Eskisehir, Turkiye, stopuz@ogu.edu.tr (ORCID ID: 0000-0002-7761-6255) 


\section{Giriş}

İyi işleyen bir finansal sistem firmaların dış finansman kısıtlarının azaltılması, tasarrufların mobilizasyonu, sermaye birikiminin artırılması, vade dönüşümü, kaynakların etkin tahsisi ve verimlilik büyümesi gibi faydalar sağlayarak iktisadi büyümenin hızlanmasına yardımcı olmaktadır (Beck, Levine ve Loayza, 2000; Wurgler, 2000; Love, 2003; Levine, 2005). İyi işleyen bir finansal sistemin en önemli göstergesi ise kredi piyasasının istikrarlı oluşudur. İstikrarlı kredi piyasaları fonların çok çeşitli iktisadi aktörlere ve alanlara aktarılabilmesini sağlayarak finansal gelişmenin iktisadi büyümeyi etkileyen temel dinamiklerinin başında gelmektedir.

Finansal kurumlar tarafından verilen krediler, finansal sistem ve iktisadi büyüme ilişkisinde önemli bir yere sahip olmasına rağmen hızlı kredi büyümesi özellikle gelişmekte olan ülkelerin gelecek finansal ve iktisadi krizlerden etkilenme düzeyini de belirleyebilmektedir (Obstfeld ve Rogoff, 2010; Gourinchas ve Obstfeld, 2012). Kredi koşullarına daha fazla bağımlı olan iktisadi aktörlere sahip ekonomiler kredi yavaşlaması dönemlerinde daha hassas olabilir ve bu ülkelerde temerrüte düşen hanehalkı ve firmalar artabilir. Diğer taraftan aşırı kredi genişlemesi kredi kalitesini düşürebilir, bankacılık sisteminin istikrarını etkileyerek sistemik riski artırabilir ve ayrıca varlık fiyatlarında balonlara yol açarak finansal krizlere neden olabilir (Borio, Furfine ve Lowe, 2002; Borio ve Drehmann, 2009; Igan ve Pinheiro, 2011; Alessi ve Detken, 2014). Bu nedenle de kredilerdeki genişlemeyi nelerin belirlediği sorusunun anlaşılması makroekonomik ve finansal istikrar açısından oldukça önemli hale gelmektedir.

Kredi büyümesi iktisadi büyüme, enflasyon, uluslararası sermaye akışı ve faiz oranları, para politikası koşullarının gevşekliği ya da sıkılığı, finansal sistemin ve bankacılık sektörünün karlılı̆ı ya da sağlığı gibi arz ve talep yanlı koşullardan etkilenebilmektedir (Calza, Gartner ve Sousa, 2003; Elekdag ve Wu 2011; Guo ve Stepanyan 2011; Imran ve Nishat, 2013; Gözgör, 2014;). Talep koşulları bakımından hızlı bir iktisadi büyüme hem hanehalkı hem de şirketlerin beklenen gelir ve karlılıklarını artırabilir. Güçlü iktisadi büyüme iktisadi aktörlerin krediler aracılığıyla daha yüksek tüketim ve yatırımı finanse edebilmesi için daha yüksek bir borçluluk düzeyinin sürdürülebilmesine imkân sağlar (Kashyap, 1993). Dahası iktisadi aktivite ve verimlilikteki artış beklentisi net bugünkü değer bakımından karlı hale gelen yatırım projesi sayısında artışa yol açarak daha yüksek kredi talebi yaratabilir (Calza vd., 2003). Diğer yandan talep koşulları bakımından iktisadi büyümenin kredi büyümesi üzerinde tersine bir etki yaratacağını düşünmek de mantıklı olabilir. Nakit akışı hipotezine göre gelecekten ziyade bugünkü verimlilik artışının yarattığı gelir ve kar akışı firmaları ve iktisadi aktörleri farklı davranmaya itebilir. Nakit akışından kaynaklı olarak dış finansman ihtiyacındaki azalıştan dolayı bu aktörler nakit akışı fırsatlarını borçluluğun azaltılması amacıyla kullanabilir. Harcanabilir gelir ve karlılığın azaldığı dönemlerde ise hanehalkı ve firmaların nakit akışlarındaki azalmanın etkisini düzleştirebilmek için kredi talebini artırabilir. (Friedman ve Kuttner, 1993; Bernanke ve Gertler, 1995). Dolayısıyla bu koşullar iktisadi büyüme ve kredi büyümesi arasında tersine bir ilişki yaratabilir.

Kredileri etkileyen arz kaynaklı faktörlerin başında kredi maliyet koşulları yer almaktadır. Kredi maliyetleri büyük oranda ödünç alınan fonların maliyeti olan faiz oranlarına bağılır. Kredi maliyetlerindeki artışlar kredi arzının azalmasına yol açacaktır. Ancak kredilerin fiyatı, faiz maliyetlerinin yanında alternatif finansman kaynaklarının maliyeti gibi fırsat maliyetlerini de yansıtabilir (Friedman ve Kuttner, 1993; Calza vd., 2003). Hanehalkı gibi bankacılık dışı finansman kaynaklarına erişimi zor olan iktisadi gruplar için diğer kaynaklardan finansman sağlamanın etkileri düşük olabilecekken firmalar alternatif finansman kaynaklarının maliyetindeki değişimlere daha duyarlı olabilir. Kredi maliyetlerini belirleyen en önemli faktörlerin başında ise para politikası duruşu gelmektedir. Para politikasının gevşetilmesi kredi maliyetlerini düşürerek kredi arzını artırabilir. Diğer taraftan küresel likidite koşullarının bolluğu ve sermaye girişlerinin de benzer etkiler yaratabileceği söylenebilir (Mendoza ve Terrones, 2008; Elekdag ve Wu, 2011).

Türkiye'nin düşük tasarruf oranlarına sahip olması ve dolayısıyla mevcut kredi talebinin karşılanabilmesi için dış finansmana ihtiyaç duyması, onun sermaye akışındaki ani duruşlar ve döviz kuru baskıları karşısında daha hassas bir kredi piyasası yapısına sahip olmasına neden olabilmektedir. Dolayısıyla hızlı kredi genişlemesinin pozitif etkileri ne kadar yüksek ise kredi genişlemesindeki ani yavaşlamaların etkisi de bir o kadar yüksek olabilmektedir. Dahası hızlı kredi genişlemesi Türkiye'de hala üstesinden gelinememiş 
olunan enflasyon probleminin hızlanmasını da beraberinde getirebilmektedir. Bu koşullarda Türkiye'de kredi arzını ya da büyümesini belirleyen faktörlerin ortaya çıkarılması, istikrarlı iktisadi koşullar oluşturabilmek amacıyla uygulanacak politikaların tespit edilmesi bakımından son derece önemlidir. Ancak aksine Türkiye'de kredi büyümesinin belirleyicileri üzerine yapılan çalışmalar son derece azdır. Dolayısıyla bu çalışma Türkiye'de kredi büyümesinin hangi iktisadi koşullar tarafından yönlendirildiğini ortaya çıkarmayı amaçlamaktadır. Bu kapsamda 2006 ve 2019 arası dönemde kredi büyümesinin temel makro iktisadi koşullar, para politikası duruşu, dış talep ve küresel likidite koşulları ve banka fon yapısı ve karlılığına yönelik değişkenlerle ilişkisi incelenmektedir. Dolayısıyla bu çalışma daha çeşitli iktisadi değişkenlerin etkisini inceleyerek Türkiye için yapılan daha önceki çalışmalardan farklılaşmaktadır. Diğer yandan kredi genişlemesinin genellikle konjonktürel oluşu ve farklı dönemlerde farklı koşullar tarafından yönlendirilmesi de söz konusu olabilmektedir. Bu çerçevede kredi büyümesini belirleyen faktörlerin kredi büyümesi ile zaman içinde nasıl bir ilişkiye sahip olduğunu ortaya koyabilmek için diğer çalışmalardan farklı olarak zamanla değişen bir nedensellik yaklaşımı kullanılmaktadır.

Çalışma elde edilen bulgular makro iktisadi koşullar, para politikası duruşu, dış talep ve küresel likidite ve bankalara özgü koşulların kredi büyümesini yönlendirmede oldukça etkili olduğu ve yönlendirici etkinin zamanla değişen bir doğaya sahip olduğu biçimindedir. Çalışmanın kalan kısmı dört bölüm olarak tasarlanmaktadır. İkinci bölümde özellikle gelişmekte olan ülkelerde kredi büyümesinin belirleyicilerini inceleyen çalışmaların bulgularına yer verilmektedir. Üçüncü bölümde veri seti ve yöntem, dördüncü bölümde ekonometrik tahminlerden elde edilen bulgular sunulmaktadır. Beşinci ve son bölümde sonuç ve değerlendirme yer almaktadır.

\section{Literatür}

Kredi büyüme oranının belirleyicilerini tespit edebilmek için yapılan çalışmalar talep ve arz yönlü veya her iki yöndeki faktörleri birlikte ele alabilmektedir. Bu kısımda genellikle daha güncel ve Türkiye'ye benzer gelişmekte olan ülkeler için yapılan çalışmalar özetlenmektedir.

Illk olarak ilgili literatürde farklı ülke grupları için panel veri analizi yöntemiyle kredi büyümesinin belirleyicilerini inceleyen çalışmalar dikkat çekmektedir. Bu çalışmalarda hem kullanılan değişkenler birbirinden farklılık göstermekte; dolayısıyla hem de sonuçları itibariyle benzer ve farklı yönleri bulunmaktadır. Örneğin; Calza vd. (2003), Euro bölgesindeki özel sektöre sağlanan kredilerin belirleyici faktörlerini sorgulamaktadır. 1980:1-1999:2 dönemi baz alınarak yapılan analizden elde edilen sonuçlara göre uzun dönemde reel GSYiH, kredileri pozitif etkilerken reel faiz oranları ise hem kısa hem de uzun dönemde negatif etkilemektedir. Ayrıca uzun vadeli faiz oranının kredi büyümesi üzerindeki etkisi kısa vadeli faiz oranından daha büyüktür. Diğer yandan Calza vd. (2003) çalışmasından farklı olarak gelişmekte olan ülke gruplarına odaklanan çalışmalar da mevcuttur. Bu çalışmalardan biri olan Guo ve Stepanyan (2011), 38 gelişmekte olan ülkenin 2001:1-2010:2 dönem verilerini baz alarak banka kredilerindeki değişimi incelemektedir. Diğer çalışmalara kıyasla daha geniş kesit ve zaman boyutuna sahip veri seti ile yapılan çalışmada yurtiçi ve yurtdışı finansmanın kredi büyümesini pozitif etkilediği ileri sürülmektedir. Kredi büyümesi ve ekonomik büyüme pozitif ilişkili iken enflasyon ise nominal kredileri arttırırken reel kredi büyümesini olumsuz etkilemektedir. Gevşek para koşulları ile ilgili olarak ise kredi miktarını arttırdığına dair bulgulara rastlanmaktadır. Sharma ve Gounder (2012), Güney Pasifik'teki altı ekonomi özelinde özel sektöre verilen banka kredilerindeki değişiklikleri incelemektedir. 1982-2009 dönem verileri ile yapılan çalışmada borç verme faiz oranlarının ve enflasyonun yükselmesinin kredi büyümesini olumsuz etkilediği; mevduat ve varlıklar üzerindeki etkisinin ise olumlu olduğuna dair kanıtlara ulaşılmaktadır. Benzer şekilde ekonomik büyümenin de kredi büyümesini pozitif etkileyen bir faktör olduğu belirtilmektedir. Bu üç çalışmada kullanılan ortak değişkenlere ait elde edilen sonuçlar birbiri ile kıyaslandığında temelde ekonomik büyüme ile kredi büyümesi arasındaki ilişkinin pozitif, enflasyon ile kredi büyümesi arasındaki ilişkinin ise negatif olduğu söylenebilir. Diğer yandan ekonomik büyüme için benzer fakat enflasyon için farklı sonuçlar elde eden Awdeh (2017), Lübnan'daki 34 ticari banka kredi büyümesini 2000-2015 dönemi temelinde incelemektedir. Ampirik analizden elde edilen temel bulgular mevduat artışının, GSYiH büyümesinin, enflasyonun ve para arzının özel sektöre sağlanan banka kredisini artırdığını göstermektedir. Ancak diğer yandan kredi riski, borç verme faiz 
oranı, T fatura oranı, kamu borçlanması ve havale girişleri kredi büyümesini azaltmaktadır. Nijerya'da banka kredilerini etkileyen baskın faktörleri sorgulayan Akinlo ve Oni (2015), 1980-2010 dönem verilerini kullanmaktadır. Elde edilen bulgular geniş para arzı (M2), konjonktürel risk primi ve likidite oranının özel sektör kredilerini arttırma eğiliminde olduğunu göstermektedir. Kredi faiz oranı ve rezerv oranı ise krediler üzerinde azaltıcı etkiye sahiptir. Yazarlar enflasyon için ise Awdeh (2017) çalışmasına benzer olarak reel kredi miktarı üzerinde pozitif etkisinin olduğunu göstermektedir. Tüm bu çalışmalardan farklı sonuçlar elde eden bir diğer çalışma ise Thaker, Ee, Sin ve Man (2013)'e aittir. Yazarlar, Malezya'da makroekonomik değişkenlerin banka kredisi üzerindeki etkisini sorgulamakta ve 1991-2011 dönemine ait aylık veri seti kullanmaktadır. Çalışmada borç verme oranı, tüketici fiyat endeksi ve GSYiH olmak üzere üç değişken incelenmekte ve bu üç değişkenin de banka kredileri üzerinde pozitif etkileri olduğunu göstermektedir. Imran ve Nishat (2013) ise arz yönlü faktörlere odaklanarak Pakistan'da banka kredilerinin belirleyicilerini sorgulamaktadır. 1971-2010 dönemi temel alınarak yapılan analizde uzun dönemde banka kredileri üzerindeki önemli etkileri olabilecek faktörleri: yabancı borçlar, yurtiçi mevduatlar, ekonomik büyüme, döviz kuru ve parasal koşullar olarak sıralamaktadır. Yazarlar, pek çok faktörün kredi büyümesi üzerinde önemli etkileri olduğunu iddia ederken enflasyon ve yurtiçi mevduat değişkeni için elde ettiği sonuçlar bakımından diğerlerinden farklılaşmaktadır. Enflasyon ve para piyasası oranının özel krediler üzerinde anlamlı bir etkisi bulunmamaktadır ve kısa vadede de yurtiçi mevduatların özel kredi üzerinde etkisine rastlanamamaktadır.

Tan (2012), Filipinler'de 2002:Q4-2010:Q4 dönemini temel alarak özel sektör kredisinin büyümesinin belirleyicilerini araştırmaktadır. Çalışmanın bulgularına göre yüksek net faiz marjları özel kredi büyümesini caydırıcı özellikte iken yatırım yanlı büyüme ve mevduat büyümesi, özel kredi büyümesine olumlu katkıda bulunmaktadır. Ayrıca sonuçlar tüketim odaklı büyüme, Fed faiz oranında ve sorunlu varlıkların oranındaki artışların özel kredilerde düşmeye neden olduğunu göstermektedir. Arz ve talep göstergelerine dayalı olarak Arnavutluk için özel sektöre sağlanan banka kredilerinin uzun vadeli belirleyicilerini inceleyen Shijaku ve Kalluci (2013) ilk olarak kredi sağlamanın ekonomik büyüme üzerindeki pozitif etkilerini ortaya koymaktadır. Çalışmanın diğer bulgularına göre finansal aracılık ve finansal serbestleşme daha yüksek borç verme talebini teşvik edecektir. Ayrıca devlet iç borcunun azalması, düşük borçlanma maliyeti ve daha nitelikli banka kredilerinin sağlanabilmesi kredi vermeyi teşvik edecektir. Gözgör (2014) 24 gelişmekte olan ülkenin 20002011 dönemi boyunca yurtiçi kredi genişlemesinin belirleyicilerini tespit etmeyi amaçlamaktadır. İç talep ve dış arz faktörlerinin yurtiçi kredi miktarı üzerindeki kısa ve uzun vadeli etkilerinin incelendiği ampirik analizde iç piyasadaki gevşek para politikasının, yurtiçi ve küresel borç verme faiz oranı arasındaki farkın ve reel ticaret açıklığının yurtiçi kredi miktarını pozitif etkilediği sonucuna ulaşılmaktadır. Bunun yanı sıra dış denge ve küresel kuyruk riski algılarının ise negatif etkilediği belirtilmektedir. Ayrıca elde edilen bulguların sağlamlığı da 2008-2009 yılında yaşanan büyük küresel durgunluğun dönem etkisi dikkate alınarak da kontrol edilmektedir. Elekdağ ve Han (2015), gelişmekte olan Asya ülkeleri için kredi büyümesine neden olan temel faktörleri tespit etmeyi amaçlamaktadır. Çalışmada Asya'daki kredi patlamaları, diğer tüm gelişmekte olan ekonomilere göre krizlerin daha büyük oranda etkisi ile ortaya çıktığından bu ülke grubu seçilmektedir. Çalışmada yapısal vektör otoregresif (SVAR) modeli kullanılmaktadır. Elde edilen bulgulara göre, ülke içi faktörler kredi büyümesini tetikleyen dış faktörlerden daha baskındır; özellikle de ülke içi para politikası için geçerlidir. Ayrıca döviz kuru esnekliğindeki artış ise yurtiçi kredi dinamiklerini etkileyen dış faktörlerin rolünü azalttığı için finansal istikrarı da teşvik edebilmektedir.

Literatürde kredi büyümesinin belirleyicilerini finansal kriz dönemlerini dikkate alarak inceleyen çalışmalar da yer almaktadır. Çalışmalarında banka kredi büyümesinde banka sahipliğinin rolüne odaklanan Chen ve Wu (2014) gelişmekte olan ülkeleri incelemektedir. Yazarlar 2008-09 krizini temel alarak zaman dilimini kriz öncesi, sonrası ve kriz esnası olarak belirlemektedir. Yerli bankaların kredi büyümesi Asya, Latin Amerika ve gelişmekte olan Avrupa'da kriz sonrasında yabancı bankalara göreli olarak daha yüksek görülmektedir. Yazarlar, genişletici para politikasının kredi büyümesi üzerinde pozitif etkilerinin olduğunu ve ayrıca likit varlığı ve sermayesi daha yüksek olan bankaların da daha hızlı kredi büyümesine sahip olduğunu göstermektedir. Cucinelli (2015) ise finansal kriz döneminde bankaların borç verme davranışının nasıl olacağını kredi sıkıntısı çeken ülkelerden biri olan i̇talya için incelemektedir. Çalışmanın temel amacı kriz döneminde özellikle kredi riskinin artmasından kaynaklı etkiyi tespit etmektir. 2007-2013 dönemi borsada işlem gören ve görmeyen banka verisi ile yapılan analizde önceki yılın kredi riskinin bankaların kredi sağlama 
davranışını olumsuz etkilediği ileri sürülmektedir ve bu sonuç finansal kriz sırasında hem ticari hem de kooperatif bankaları için farklıık göstermemektedir. Kredi büyümesinin belirleyicilerini Karadağ için sorgulayan Ivanović (2016) arz ve talep yönlü faktörleri araştırmakta ve daha çok arz yönlü faktörlere dikkat çekmektedir. Ülkenin kalkınmasına yönelik gelişmeleri ve banka mevduatlarındaki artışı kredi büyümesini pozitif etkileyen faktörler olarak sıralarken; takipteki kredilerin artışı ve düşük ödeme gücü oranı ise kredi arzını olumsuz etkileyen faktörlerdendir. Ayrıca Chen ve Wu (2014) çalışmasına benzer olarak küresel finansal kriz dönemini de baz alarak yaptığı dönem ayrıştırmasında, kredi arzı göstergeleri kriz sonrası dönem için kredi büyümesi üzerinde belirleyici iken hem talep hem de arz göstergelerinin belirleyiciliği kriz öncesi dönemde önem kazanmaktadır. Kriz dönemlerinin banka faaliyetlerine muhtemel etkilerinin olması göz önünde bulundurularak yapılan bu çalışmalar ise bu yönleri ile diğerlerinden farklılaşmaktadır. Öne çıkan temel sonuçlara göre kriz döneminde riskin artması nedeniyle banka türlerine göre kredi arzının olumsuz etkilenebileceği; kriz öncesi ve kriz sonrası dönemde ise kredi büyümesinin belirleyicilerinin farklı faktörler olduğu söylenebilir.

Son olarak literatürde sınırlı da olsa Türkiye ile ilişkili olarak yapılan çalışmalar da mevcuttur. Türkiye'de özel ve devlet bankalarının 2003-2012 dönemine ait verilerini kullanarak kredi verme davranışının belirleyicilerini sorgulayan Tomak (2013), büyüklük ve fona erişim gibi banka düzeyi odaklı ve faiz oranı, enflasyon ve GSYiH gibi piyasa temelli değişkenleri kullanmaktadır. Analiz sonuçları bankaların kredi sağlama performansının; bankaların büyüklüğüne, toplam borçlarına, toplam krediler içindeki takipteki kredi miktarına ve enflasyon oranına bağlı olduğunu göstermektedir. Ancak bulgular faiz oranı ve GSYiH değişkenlerinin ise anlamlı etkiler yaratmadığına işaret etmektedir. Türkiye için özel sektör işletme kredilerinin belirleyicilerini inceleyen bir çalışma da Yiğitbaş (2015)'a aittir. Yazar çalışmada kredi faiz oranları, ekonomik faaliyet ve reel kesim güven endeksinin krediler üzerindeki etkilerini 2003:1-2012:12 dönemini baz alarak incelemektedir. Elde edilen bulgulara göre özel sektör kredilerinin, faiz oranı ve ekonomik faaliyetteki değişimlere duyarlı olduğunu ancak reel kesim güven endeksinin ise duyarsız olduğu belirtilmektedir. Alihodžić ve Ekşi (2018) ise Batı Balkan ülkelerindeki kredi büyüme oranı üzerinde etkili olan içsel ve dışsal faktörler ile Türkiye'nin kredi politikası incelenmektedir. 2007:Q1-2017:Q2 dönem verileri kullanılarak yapılan çoklu regresyon analizinde takipteki kredi oranı ile kredi büyümesi arasında negatif ilişki olduğu; sorunlu kredilerin toplam krediler içindeki payı ile bankaların risk alma ve kredi büyümesi yönündeki genel eğilimi arasındaki ilişkinin de negatif olduğu gösterilmektedir. Diğer yandan ekonomik büyüme, mevduatların büyüme hızı ve Hırvatistan hariç öz sermaye getiri oranı ile kredi büyümesi arasında ise pozitif bir ilişki elde edilmektedir.

Illgili literatür bütün olarak incelendiğinde kredi büyümesini etkileyen pek çok farklı faktör olduğu söylenebilir. Diğer yandan Türkiye'de kredi büyümesinin belirleyicilerini tespit etmeye yönelik çalışmalar oldukça azdır; mevcut çalışmalar ise kredi büyümesini etkileyen faktörlerin dönemler itibariyle farklı olabileceğini hesaba katmamaktadır. Bu nedenle bu çalışmada çeşitli iktisadi değişkenlerin kredi büyümesi üzerindeki etkisinin zaman içinde nasıl olacağını tespit etmeye imkân sağlayan zamanla değişen nedensellik yaklaşımı metodu seçilmekte ve elde edilecek bulguların bu açıdan da literatüre katkı sağlaması beklenmektedir.

\section{Veri Seti ve Yöntem}

\subsection{Veriler}

Türkiye'de kredi büyümesinin belirleyicilerini tespit edebilmek amacıyla daha önceki çalışmalarda sıklıkla başvurulan bankacılık sektörüne ilişkin değişkenlerin yanı sıra ülkenin makro iktisadi koşullarını, para politikası duruşunu ve dış talep ve küresel likidite koşullarını temsil eden değişkenleri kapsayan bir veri seti kullanılmaktadır. Veriler çeyreklik sıklıkta ve 2006 yılı birinci çeyreğinden 2019 yılı dördüncü çeyreğine kadar 56 gözlemden oluşmaktadır. Kredi büyümesi değişkeni için bankalar ve finansal kuruluşların toplam kredi hacminin büyüme oranı kullanılmaktadır. Ülkenin makro iktisadi koşullarına ilişkin değişkenler sırasıyla GSYH'nin büyüme oranı, enflasyon oranı ve kamu borcu büyüme oranıdır. GSYH değişkeni harcama yöntemi ile zincirlenmiş şekilde hesaplanırken enflasyon tüketici fiyatları endeksindeki yüzde değişim olarak 
hesaplanmaktadır. Kamu borcu ise kamu iç ve dış borç stokunun toplamından oluşmaktadır. Bankacılık sektörünün durumu ise sırasıyla kredi faizleri mevduat büyüme oranı, toplam varlıklarının karlılık oranı (ROA) ve öz sermayenin karlılık oranı (ROE) değişkenleri ile temsil edilmektedir. Kredi faizleri değişkeni bankalarca intiyaç, tüketici, konut, taşıt ve ticari kredilere uygulanan ağılıklı ortalama faiz oranlarının aritmetik ortalaması biçiminde hesaplanmaktadır. Toplam varlıklarının karlııı oranı, net karın toplam varlıklara, öz sermayenin karlılık oranı ise net karın öz sermayeye bölünmesi biçiminde hesaplanmaktadır. Para politikası duruşunu temsil etmek amacıyla M2 para arzının büyüme oranı ve TCMB'nin gecelik borç verme faiz oranları kullanılmaktadır. Dış talep ve küresel likidite koşullarını temsil etmek amacıyla Dolar/TL döviz kuru alış ve satış ortalamasının yüzde değişimi, $A B D$ federal fon oranı ve sermaye girişlerindeki değişim kullanılmaktadır. Sermaye girişi değişkeni hisse senedi, devlet iç borçlanma senetleri, repo ve özel sektör tahvil ve bonoları stoklarının toplamındaki yüzde değişim şeklinde hesaplanmaktadır. ABD federal fon oranı Federal Reserve Economic Data (FRED), St. Louis Fed veri tabanından elde edilirken diğer değişkenlerin tümü TCMB elektronik veri dağııı sisteminden (EVDS) elde edilmektedir. Çalışmada kullanılan bu değişkenlerin tanımlayıcı istatistikleri ve grafikleri sırasıyla Tablo 1 ve Grafik 1'de gösterilmektedir.

Tablo 1. Değişkenlere Ait Tanımlayııı İstatistikler

\begin{tabular}{|l|c|c|c|c|c|c|}
\hline Değişkenler & Ort. & Medyan & Maks. & Min. & St. Hata & Gözlem Sayısı \\
\hline Krediler \% & 0,054 & 0,055 & 0,174 & $-0,074$ & 0,037 & 56 \\
\hline GSYH Büyüme Oranı \% & 4,816 & 5,715 & 11,680 & $-14,380$ & 4,892 & 56 \\
\hline Enflasyon \% & 0,023 & 0,024 & 0,066 & $-0,003$ & 0,015 & 56 \\
\hline Kamu Borcu \% & 0,020 & 0,017 & 0,083 & $-0,037$ & 0,022 & 56 \\
\hline M2 Para Arzı \% & 0,042 & 0,038 & 0,123 & $-0,040$ & 0,028 & 56 \\
\hline TCMB O/N Faiz Oranı & 13,620 & 11,000 & 25,500 & 6,500 & 5,862 & 56 \\
\hline ABD Federal Fon Oranı & 1,243 & 0,276 & 5,256 & 0,073 & 1,661 & 56 \\
\hline Sermaye Girişi \% & 0,011 & 0,021 & 0,384 & $-0,374$ & 0,157 & 56 \\
\hline Döviz Kuru \% & 0,028 & 0,013 & 0,278 & $-0,075$ & 0,070 & 56 \\
\hline Kredi Faizleri \% & 0,006 & $-0,013$ & 0,641 & $-0,278$ & 0,144 & 56 \\
\hline Mevduatlar \% & 0,042 & 0,042 & 0,120 & $-0,040$ & 0,028 & 56 \\
\hline ROA & 0,011 & 0,010 & 0,026 & 0,002 & 0,006 & 56 \\
\hline ROE & 0,089 & 0,092 & 0,192 & 0,025 & 0,043 & 56 \\
\hline
\end{tabular}

Grafik 1. Değişkenlere Ait Grafikler
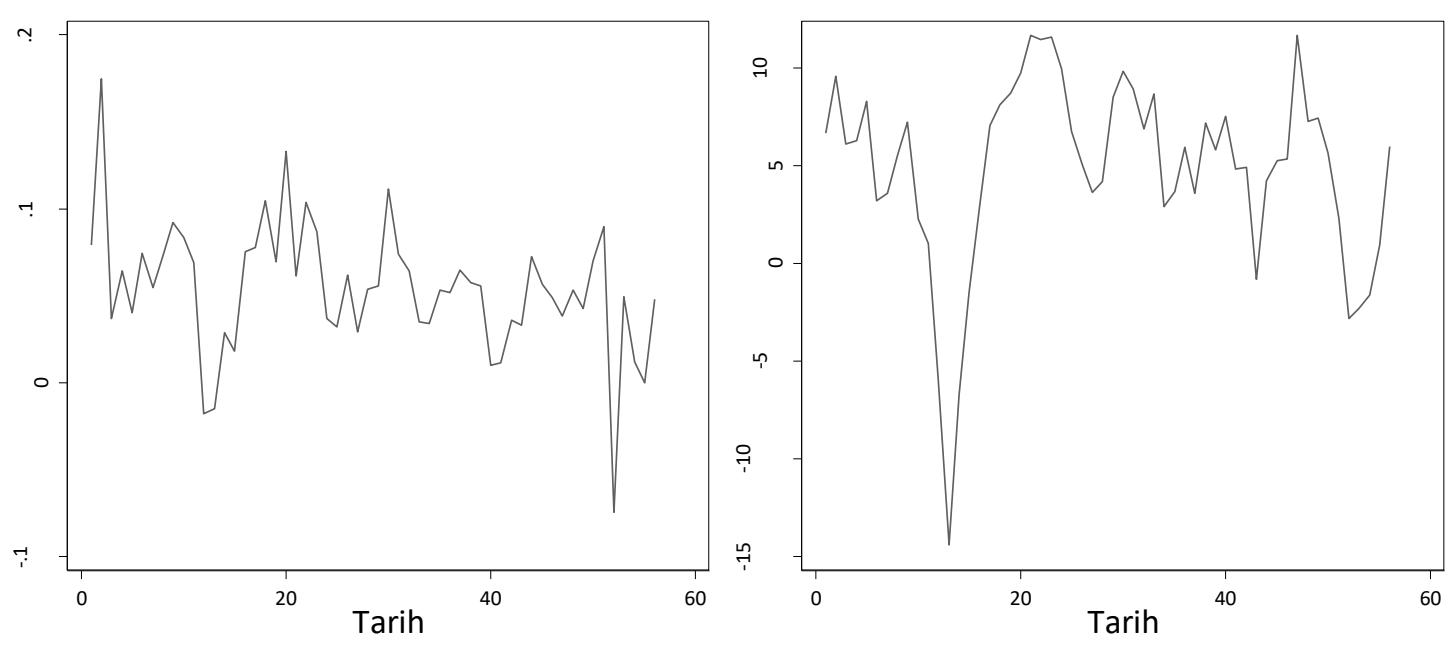
Grafik 1. Değişkenlere Ait Grafikler (Devamı)
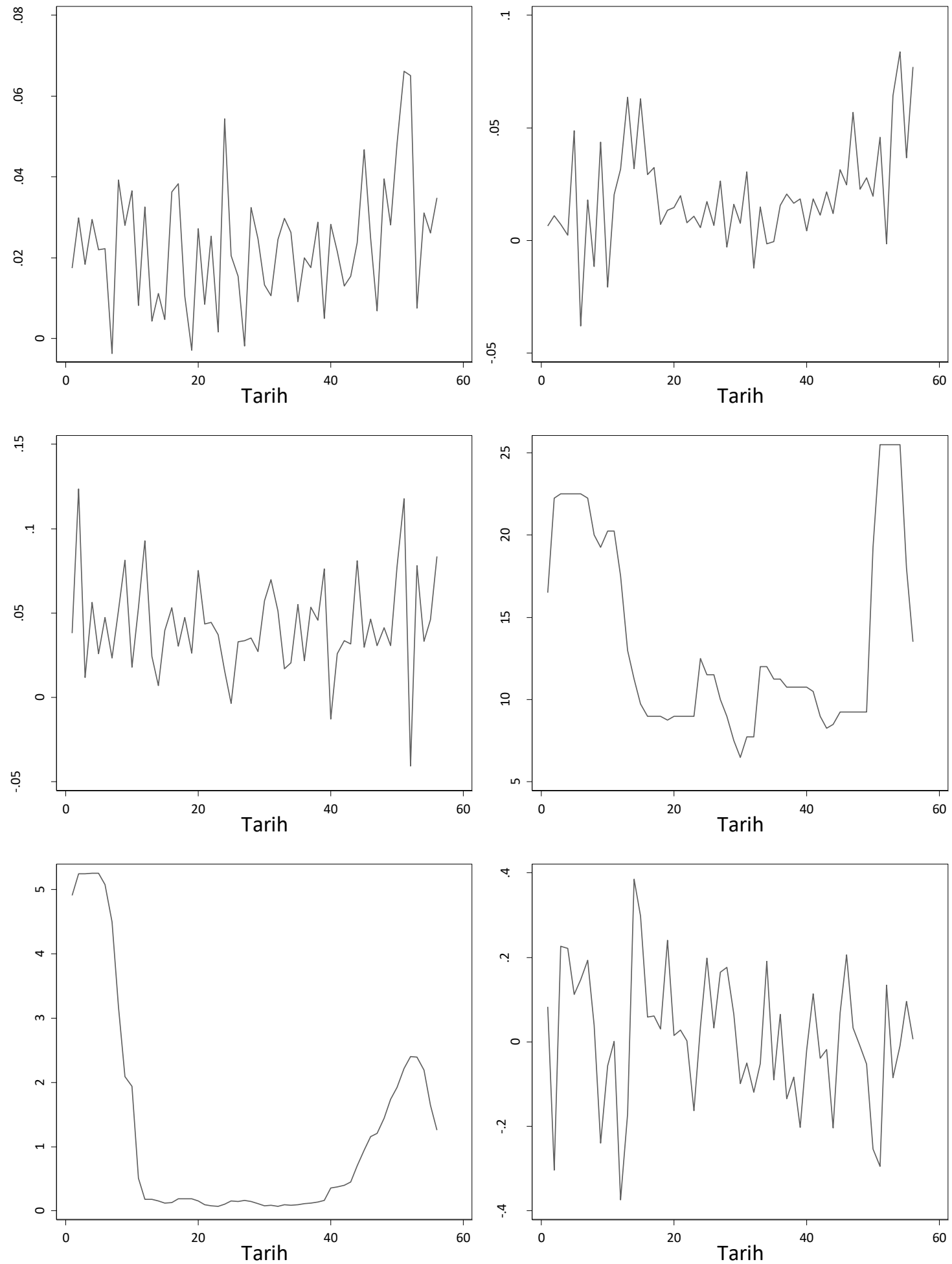
Grafik 1. Değişkenlere Ait Grafikler (Devamı)
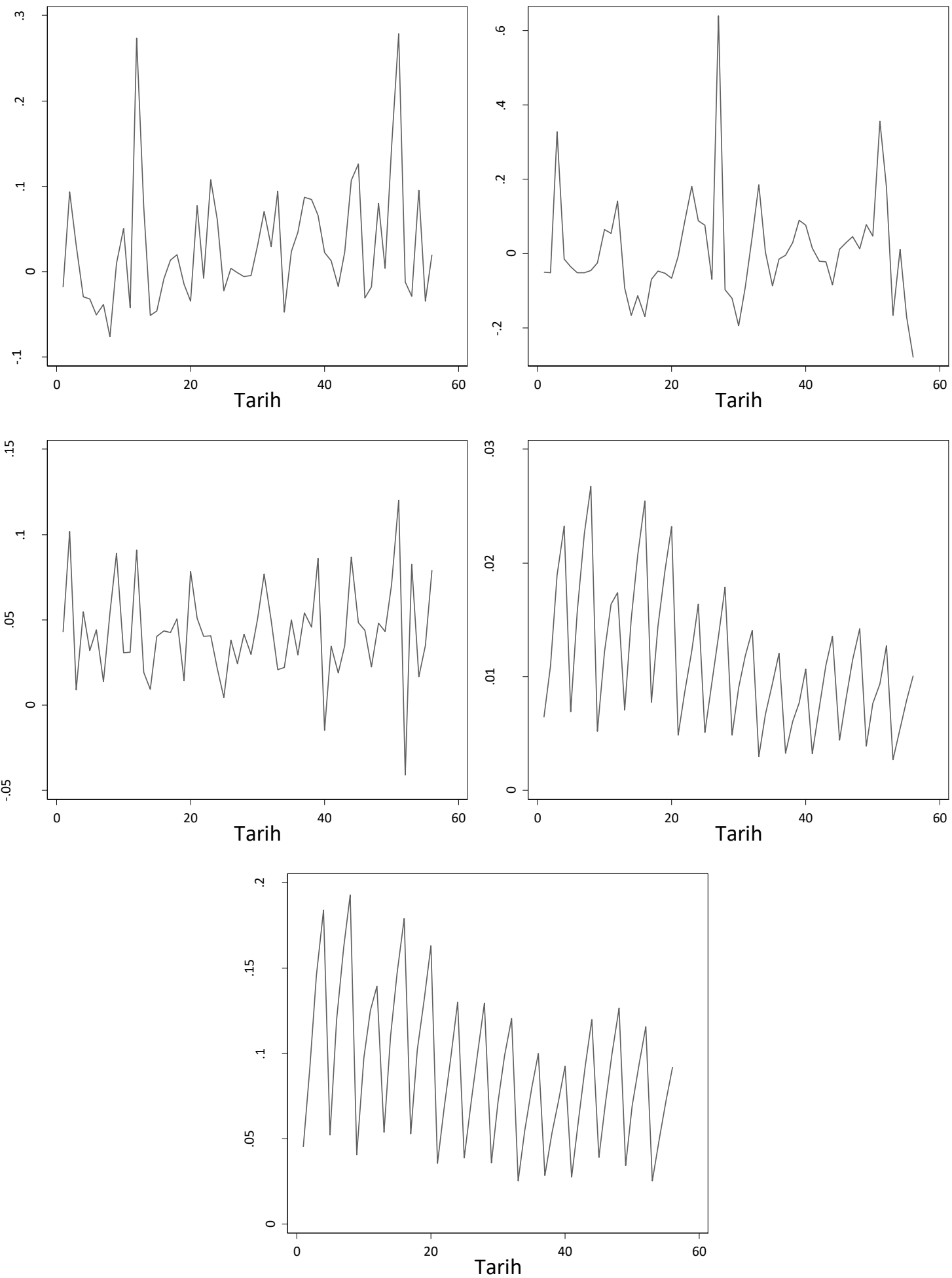

\subsection{Yöntem}

VAR modeli temelinde Granger nedenselliği test etmek için Wald, olabilirlik oranı (LR) ve Lagrange çarpanı (LM) testi gibi sıkça kullanılan test istatistikleri, eğer VAR modelinde kullanılan değişkenler tümleşik veya eşbütünleşik ise standart olmayan asimptotik özelliklere sahip olabilmektedir. Toda ve Yamamoto (1995) ve Dolado ve Lütkepohl (1996) değişkenlerin I(1) olduğu VAR (p) süreçlerinin katsayıları ile hesaplanan Wald test istatistikleri için standart asimptotik dağılımı garanti eden bir çözüm önermektedir. Sıfır hipotezi altında en az bir katsayı matrisinin kısıtsız olmasını gerektirmektedir (Balcılar, Özdemir ve Arslantürk, 2010: 
1399). Bu çalışmada kullanılan zamanla değişen nedensellik testi ise Hacker ve Hatemi-J (2006)'nin Toda ve Yamamoto (1995) testine dayalı olarak geliştirdiği bootstrap nedensellik testine dayanmaktadır. Bootstrap LR Granger nedenselliği test edebilmek için öncelikle iki değişkenli temel VAR(p) modeli (Balcılar vd., 2010: 13991400):

$$
y_{t}=\mu_{0}+\mu_{1} y_{t-1}+\cdots+\mu_{p} y_{t-p}+\varepsilon_{t}, \quad t=1,2, \ldots, T
$$

$y_{t}, \mu_{0}$ ve $\varepsilon_{t} n$ boyutlu vektör iken $\mu_{r}$ ise $r$. gecikme için elde edilen parametrelerin $\mathrm{n} \times \mathrm{n}$ matrisi olarak tanımlanmaktadır. Hata vektörü $\varepsilon_{t}$ için tekil olmayan kovaryans matrisi $\sum$ ile sıfır ortalamadan bağımsız beyaz gürültü süreci geçerlidir. Burada, $p$ gecikme uzunluğu Akaike Bilgi Ölçütü (AIC) kullanılarak belirlenmektedir.

Toda ve Yamamoto (1995) bütünleşik değişkenler arasındaki nedensellik ilişkisini test etmek için genişletilmiş $V A R(p+d)$ modeli önermektedir:

$$
y_{t}=\hat{\mu}_{0}+\hat{\mu}_{1} y_{t-1}+\cdots+\hat{\mu}_{p} y_{t-p}+\hat{\mu}_{p+d} y_{t-p-d}+\hat{\varepsilon}_{t}, \quad t=1,2, \ldots, T
$$

Denklemde parametrelerin üzerindeki " $\wedge$ " simgesi EKK ile tahmin notasyonu için kullanılmaktadır. Ayrıca $p$, optimal gecikme uzunluğunu ve $d$, maksimum bütünleşme derecesini temsilen kullanılmaktadır. Modelde maksimum eşbütünleşme derecesi ise değişkenlerin birim kök testleri aracılığıyla belirlenmektedir. Tahmin yapılmadan önce örneklem boyutu $\mathrm{T}$ için ise birtakım tanımlamalar yapılmaktadır. Burada $\mathrm{Y}:=$ $\left(y_{1}, \ldots y_{T}\right),(n x T)$ matrisi $\widehat{D}:=\left(\hat{\mu}_{0}, \hat{\mu}_{1}, \ldots \hat{\mu}_{p}, \ldots, \hat{\mu}_{p+d}\right),(n x(1+n(p+d))$ matrisi olarak ifade edilirken;

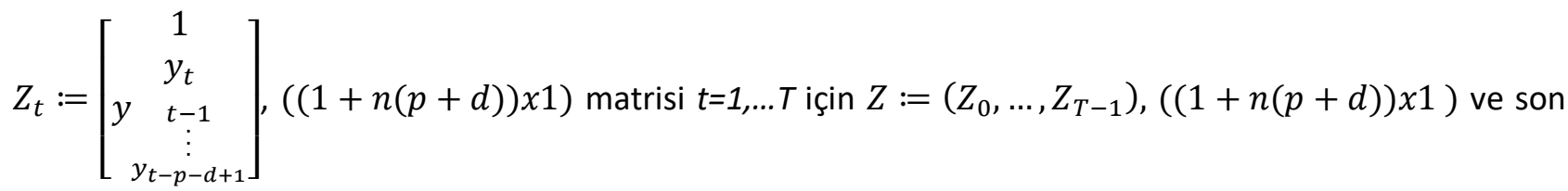
olarak $\hat{\delta}:=\left(\hat{\varepsilon}_{1}, \ldots, \hat{\varepsilon}_{T}\right),(n x T)$ matrisi şeklinde tanımlanmaktadır. Bu tanımlamalar ışığında tahmin edilen $\operatorname{VAR}(p+d)$ modeli başka bir ifade ile aşağıdaki şekilde ifade edilebilmektedir:

$$
Y=\widehat{D} Z+\hat{\delta}
$$

Özet olarak Toda ve Yamamoto (1995) tarafından değişkenler arasındaki Granger nedenselliği test etmek için modifiye edilmiş Wald testi (MWALD) ise:

$$
M W A L D=(C \hat{\beta})^{\prime}\left[C\left(\left(Z^{\prime} Z\right)^{-1} \Theta S_{U}\right) C^{\prime}\right]^{-1}(C \hat{\beta})
$$

olarak ifade edilmektedir. Eşitlikte yer alan $\Theta$, Kronecker çarpanı ve $C$, pxn $(1+n(p+d))$ matrisidir. $S_{U}=$ $\widehat{\delta}^{\prime} \hat{\delta}_{U} / T$ olarak $\beta=\operatorname{vec}\left(\mu_{0}, \mu_{1}, \ldots \mu_{p}, 0_{n x n d}\right) \operatorname{ve} \hat{\beta}=\operatorname{vec}(\widehat{D})$ ile ifade edilmektedir. Hacker ve Hatemi J (2006), $\chi^{2}$ dağılımına sahip olan MWALD testinin bootstrap yöntemi ile kullanıldığında, sonlu örneklemde doğru boyutu sağlayamayan ve buna bağlı olarak yanıltıcı sonuçlar verebilen problemlerin aşılabileceğini ileri sürmektedir. Bu yöntem daha güvenilir kritik değerler sunarak tahmindeki sapmaları azaltabilmektedir.

Zamanla değişen nedensellik testi ise Hacker ve Hatemi-J (2006) tarafından önerilen nedensellik testinin örneklemin alt dönemlere ayrılarak her birine uygulanması temeline dayanmaktadır. Granger (1996), yapısal değişikliklerin araştırmacılar için karşılaşılabilecek en önemli problemlerden biri olabileceğini belirtmektedir; bu nedenle bootstrap nedensellik testine dayanan yuvarlanan pencere Granger nedensellik testi bu değişikliklerin etkisini incelemek için kullanılabilmektedir. Yapısal değişiklikler parametrelerde de değişikliğe neden olabileceğinden nedensellik ilişkisinin yönü zaman içinde değişebilmektedir. Bu türlü problemleri çözebilmek için de $t=\tau-l+1, \tau-l, \ldots, \tau, \tau=l, l+1, \ldots T$ ( $l$ :yuvarlanan pencere büyüklügü) için yuvarlanan pencere alt örneklemlerine nedensellik testi uygulanmaktadır. Bunun yanı sıra optimal pencere boyutu seçimi için iki kritere dikkat edilmelidir. Birincisi, parametreleri doğru bir şekilde tahmin etmek için tahminin serbestlik derecesi daha büyük bir örnekleme ihtiyaç duymaktadır. İkincisi çoklu yapısal kırılma potansiyeli, pencere boyutu içinde çoklu kırılma riskini 
azaltan daha küçük örneklemler gerektirmektedir (Balcılar vd., 2010: 1400-1403). Bu çalışmada Balcılar vd., (2010) takip edilerek pencere boyutu 20 olarak belirlenmekte ve 10000 bootstrap uygulanmaktadır. Çalışmada ele alınan örneklem ve çeyreklik veriler dikkate alındığında pencere boyutunun 20 olarak belirlenmesi beş yıllık alt dönemler için ayrı ayrı nedensellik testi yapılacağı anlamına gelmektedir. Dolayısıyla birinci pencere 2006Q1 ile 2010Q4 arası dönemi, ikinci pencere 2006Q2 ile 2011Q1 arası dönemi kapsayarak devam etmekte ve 36. ya da son pencere 2015Q1 ile 201904 arası döneme denk düşmektedir.

\section{Bulgular}

Zamanla değişen nedensellik testinin uygulaması sırasında hangi prosedürün takip edileceğini belirleyebilmek amacıyla seriler birim kök bakımından incelenmektedir. Bu amaç doğrultusunda uygulanacak testlerden biri olan Genelleştirilmiş birim kök testine (ADF) ait temel regresyonlar aşağıdaki gibidir:

$\Delta y_{t}=\beta y_{t-1}+\sum_{i=2}^{\rho} \beta_{i} \Delta y_{t-i+1}+e_{t}$

$\Delta y_{t}=\alpha_{0}+\beta y_{t-1}+\sum_{i=2}^{\rho} \beta_{i} \Delta y_{t-i+1}+e_{t}$

$\Delta y_{t}=\alpha_{0}+\beta y_{t-1}+\alpha_{2} t+\sum_{i=2}^{\rho} \beta_{i} \Delta y_{t-i+1}+e_{t}$

Denklem tahminleri ile $y_{t}$ değişkeni için birim kökün varlığını tespit etmek için $\beta=0$ olup olmadığı sınanmaktadır. Bu sınama için Dickey ve Fuller tarafından geliştirilen kritik değerler kullanılmaktadır. Gecikme uzunluklarının tespiti için ise Akaike bilgi kriteri ya da Schwarz bilgi kriteri gibi kriterlerden yararlanılmaktadır.

ADF test sonuçlarını desteklemek amacıyla ikinci bir birim kök testi olarak Phillips-Perron (1988) birim kök testi uygulanmaktadır. ADF testi hata terimlerini bağımsız ve homojen varsaymakta ve seri korelasyonu için bağımlı değişkenin gecikmeli terimlerini kullanmaktadır. Phillips-Perron (PP) birim kök testi ise gecikmeli terim kullanmaksızın seri korelasyonu dikkate alan parametrik olmayan istatistiksel yöntemler kullanmaktadır. Teste ait iki regresyon eşitliği aşağıdaki gibi ifade edilebilir:

$y_{t}=\hat{\mu}+\hat{\alpha} y_{t-1}+\widehat{e_{t}}$

$y_{t}=\tilde{\mu}+\tilde{\beta}\left(t-\frac{1}{2} T\right)+\tilde{\alpha} y_{t-1}+\widetilde{e_{t}}$

Denklemlerdeki $(\hat{\mu}, \hat{\alpha})$ ve $(\tilde{\mu}, \tilde{\beta}, \tilde{\alpha})$ geleneksel en küçük kareler regresyon katsayılarını, T gözlem sayısını $e_{t}$ hata terimini temsil etmektedir. Bu test istatistiğinin asimptotik dağıımı ADF testi ile aynıdır.

Tablo 2 değişkenlere ait Augmented Dickey Fuller (ADF) ve Phillips-Perron birim kök testleri sonuçlarını göstermektedir. Illk olarak kredi büyümesi değişkeninin I(0) olduğu görülmektedir. TCMB gecelik borç verme faiz oranı ve ABD federal fon oranı serilerinin I(0) olmadığı GSYH büyüme oranı, kamu borcu ve öz sermaye getiri oranı serilerinin ise I(0) ve I(1) olarak karışı sonuçlar verdiği görülmektedir ${ }^{1}$. Diğer değişkenlerin tümü düzey hallerinde durağandır.

Zamanla değişen nedensellik testi sonuçlarını incelemeden önce Hacker ve Hatemi (2006) geleneksel nedensellik testine ilişkin sonuçların incelenmesinde fayda bulunmaktadır. Tablo 3'de ilgili değişkenler arasındaki çift yönlü nedensellik ilişkisi için Hacker ve Hatemi (2006) testinden elde edilen sonuçlar yer almaktadır. Elde edilen test istatistiğinin kritik değerlerden büyük olması durumunda nedenselliğin bulunmadığı yönünde kurulan boş hipotez reddedilebilmektedir. 
Tablo 2. Birim Kök Test Sonuçları

\begin{tabular}{|l|c|c|c|c|}
\hline \multirow{2}{*}{ Değişkenler } & \multicolumn{2}{c|}{ ADF Birim Kök Testi } & \multicolumn{2}{c|}{ Phillips-Perron Birim Kök Testi } \\
\cline { 2 - 5 } & Sabitli & Sabit+Trend & Sabitli & Sabit+Trend \\
\hline Krediler \% & $-5,811^{* * *}$ & $-6,313^{* * *}$ & $-5,825^{* * *}$ & $-6,302^{* * *}$ \\
\hline \multirow{2}{*}{ GSYH Büyüme Oranı \% } & $-2,528$ & $-2,508$ & $-15,286^{* * *}$ & $-14,991^{* * *}$ \\
& $\left(-41,154^{* * *}\right)$ & $\left(-40,742^{* * *}\right)$ & - & - \\
\hline Enflasyon \% & $-6,829^{* * *}$ & $-7,231^{* * *}$ & $-6,859^{* * *}$ & $-7,234^{* * *}$ \\
\hline \multirow{2}{*}{ Kamu Borcu \% } & $-2,267$ & $-2,669$ & $-6,639 * * *$ & $-7,157^{* * *}$ \\
& $\left(-17,760^{* * *}\right)$ & $\left(-17,645^{* * *}\right)$ & - & $-9,633^{* * *}$ \\
\hline M2 Para Arzı \% & $-9,367^{* * *}$ & $-9,275^{* * *}$ & $-9,743^{* * *}$ & $-1,951$ \\
\hline \multirow{2}{*}{ TCMB O/N Faiz Oranı } & $-2,906^{*}$ & $-2,801$ & $-1,968$ & $\left(-4,871^{* * *}\right)$ \\
\hline ABD Federal Fon Oranı & - & $\left(-4,871^{* * *}\right)$ & $\left(-4,861^{* * *}\right)$ & $-1,709$ \\
& $-3,108^{* *}$ & $-2,678$ & $-2,250$ & $\left(-4,291^{* * *}\right)$ \\
\hline Sermaye Girişi \% & - & $(-2.831)$ & $\left(-3.921^{* * *}\right)$ & $-5,943^{* * *}$ \\
\hline Döviz Kuru \% & $-5,942^{* * *}$ & $-6,054^{* * * *}$ & $-5,910^{* * *}$ & $-6,904^{* * *}$ \\
\hline Kredi Faizleri \% & $-6,499^{* * *}$ & $-5,643^{* * *}$ & $-6,511^{* * *}$ & $-5,995^{* * *}$ \\
\hline Mevduatlar \% & $-6,070^{* * *}$ & $-5,987^{* * *}$ & $-6,046^{* * *}$ & $-11,455^{* * *}$ \\
\hline ROA & $-9,858^{* * *}$ & $-9,762^{* * *}$ & $-11,549^{* * *}$ & $-9,042^{* * *}$ \\
\hline ROE & $-0,802$ & $-3,836^{* *}$ & $-5,742^{* * *}$ & - \\
\hline
\end{tabular}

Not: ADF testinde sabitli ve sabitli-trendli t-istatistik değerleri verilmiş, gecikme uzunluğu Schwarz bilgi kriterine göre belirlenmiştir. Phillips-Perron test sonuçları test istatistik değerleridir. Optimal gecikme uzunluğu Bartlett kernel spectral estimation yöntemi ve Newey-West Bandwidth (automatic selection) kriteri kullanılarak belirlenmiştir. ***, **,* sırasıyla \%1, \%5 ve \%10 düzeyinde istatistiksel olarak anlamlılı̆̆ göstermektedir. Parantez içindeki değerler ilgili serinin birinci farkına uygulanan birim kök testi için sonuçları göstermektedir. Düzey değerleri dur ağan olan seriler için birinci fark birim kök test sonuçları rapor edilmemektedir.

Tablo 3. Hacker ve Hatemi-J (2006) Nedensellik Testi Sonuçları

\begin{tabular}{|c|c|c|c|c|}
\hline \multirow[b]{2}{*}{ Nedenselliğin Yönü } & \multirow[b]{2}{*}{ Test İstatistiği } & \multicolumn{3}{|c|}{ Kritik Değerler } \\
\hline & & $\% 1$ & $\% 5$ & $\% 10$ \\
\hline GSYH Büyüme Oranı $\rightarrow$ Kredi Büyümesi & 5,490 & 15,413 & 10,581 & 8,524 \\
\hline Kredi Büyümesi $\rightarrow$ GSYH Büyüme Oranı & 8,232 & 15,023 & 9,984 & 8,089 \\
\hline Enflasyon Oranı $\rightarrow$ Kredi Büyümesi & 1,767 & 7,234 & 4,113 & 2,875 \\
\hline Kredi Büyümesi $\rightarrow$ Enflasyon Oranı & 0,328 & 7,286 & 4,221 & 2,854 \\
\hline Kamu Borcu $\rightarrow$ Kredi Büyümesi & 0,944 & 10,383 & 6,408 & 4,868 \\
\hline Kredi Büyümesi $\rightarrow$ Kamu Borcu & 13,749 & 10,536 & 6,544 & 4,882 \\
\hline M2 Para Arzı $\rightarrow$ Kredi Büyümesi & 14,376 & 7,382 & 3,954 & 2,799 \\
\hline Kredi Büyümesi $\rightarrow$ M2 Para Arzı & 0,369 & 7,107 & 4,047 & 2,813 \\
\hline TCMB Faiz Oranı $\rightarrow$ Kredi Büyümesi & 12,702 & 11,480 & 6,869 & 5,082 \\
\hline Kredi Büyümesi $\rightarrow$ TCMB Faiz Oranı & 0,346 & 10,491 & 6,523 & 4,841 \\
\hline ABD Federal Fon Oranı $\rightarrow$ Kredi Büyümesi & 0,019 & 12,359 & 7,205 & 5,162 \\
\hline Kredi Büyümesi $\rightarrow$ ABD Federal Fon Oranı & 0,476 & 12,347 & 6,853 & 4,980 \\
\hline Sermaye Girişi $\rightarrow$ Kredi Büyümesi & 10,304 & 7,203 & 4,091 & 2,917 \\
\hline Kredi Büyümesi $\rightarrow$ Sermaye Girişi & 0,019 & 7,221 & 4,077 & 2,822 \\
\hline Döviz Kuru $\rightarrow$ Kredi Büyümesi & 12,507 & 7,522 & 4,004 & 2,772 \\
\hline Kredi Büyümesi $\rightarrow$ Döviz Kuru & 3,115 & 7,197 & 4,071 & 2,808 \\
\hline Kredi Faizleri $\rightarrow$ Kredi Büyümesi & 4,064 & 8,139 & 4,241 & 2,774 \\
\hline Kredi Büyümesi $\rightarrow$ Kredi Faizleri & 18,174 & 7,196 & 4,006 & 2,800 \\
\hline Mevduat Büyümesi $\rightarrow$ Kredi Büyümesi & 9,690 & 6,862 & 3,973 & 2,841 \\
\hline Kredi Büyümesi $\rightarrow$ Mevduat Büyümesi & 0,956 & 7,271 & 4,094 & 2,827 \\
\hline ROA $\rightarrow$ Kredi Büyümesi & 13,853 & 18,359 & 13,230 & 11,166 \\
\hline Kredi Büyümesi $\rightarrow$ ROA & 33,591 & 14,692 & 9,953 & 7,952 \\
\hline ROE $\rightarrow$ Kredi Büyümesi & 11,546 & 19,106 & 13,372 & 10,856 \\
\hline Kredi Büyümesi $\rightarrow$ ROE & 8,062 & 15,205 & 10,529 & 8,378 \\
\hline
\end{tabular}

Not: VAR modelinin maksimum gecikme uzunluğu 4 olarak belirlenmekte ve optimal gecikme uzunluğu Hatemi-J kriterine göre seçilmektedir. Test istatistiğine ait kritik değerler 10000 bootstrap kullanılarak elde edilmektedir. 
Tablo 3'deki bulgular incelendiğinde kredi büyümesinin belirleyicileri olarak düşünülen değişkenler GSYH büyüme oranı, enflasyon oranı, kamu borcu ve ABD federal fon oranı değişkenleri dışındaki tüm değişkenlerden kredi büyümesine doğru nedenselliğin varlığı istatistiksel olarak en az \%10 anlamlılık düzeyinde kabul edilmektedir. Diğer taraftan kredi büyümesinden ise yalnızca GSYH büyüme oranı, kamu borcu, döviz kuru, kredi faizleri ve ROA değişkenlerine doğru bir nedensellik ilişkisi tespit edilmektedir. Geleneksel nedensellik testleri değişkenler arasındaki uzun dönemli ilişkiyi ortaya çıkarmaktadır. Yukarıda elde edilen kredi büyümesi ile temel makro ekonomik değişkenler arasında nedensellik bulunmadığı yönündeki kanıtlar zaman boyutu bakımından ele alındığında yanıltıcı olabilir. Literatürde de görüldüğü üzere farklı dönemler için incelenen bu değişkenler arasındaki ilişkiler bazı dönemlerde daha belirgin hale gelebilirken bazı dönemlerde ise zayıflayabilmektedir. Bu nedenle kredi büyümesini belirlemesi muhtemel bu değişkenlerin alt zaman dilimlerindeki davranışlarının incelenmesi yerinde olacaktır.

Türkiye'de kredi büyümesi ile makro iktisadi değişkenler, para politikası duruşu, dış talep ve likidite koşulları ve bankalara özgü koşulları temsil eden değişkenler arasındaki zamanla değişen nedensellik testi sonuçları sırasıyla Grafik 2, Grafik 3, Grafik 4 ve Grafik 5'de yer almaktadır. Her grafiğin sol tarafındaki kısımlar kredi büyümesinin belirleyicilerinden olduğu düşünülen değişkenlerden kredi büyümesine doğru nedensellik testinin sonuçlarını gösterirken sağ taraftaki kısım ise kredi büyümesinden bu değişkenlere doğru nedensellik testi sonuçlarını göstermektedir. Grafiklerde yer alan veriler nedensellik testinden elde edilen test istatistiğinin olasılık değerlerini göstermektedir. Yatay eksene paralel çizilen kesikli çizgiler ise olasılık değerinin 0,10 olduğu durumu göstermektedir. 36 alt dönem için elde edilen olasılık değerlerinin 0.10 değerinin altında olması birinci değişken ikinci değişkenin nedeni değildir biçimindeki boş hipotezin reddedilebileceği anlamına gelmektedir.

Illk olarak makro iktisadi koşulların kredi büyümesi üzerindeki etkilerini tespit etmek amacıyla incelediğimiz GSYH büyüme oranının artması genellikle işletme ve hanehalkının borç almasını teşvik ederek banka kredileri üzerinde pozitif ve anlamlı etkilere sahip olabilir. Calza vd. (2003), Sharma ve Gounder (2012), Thaker vd. (2013) ve Awdeh (2017) bu etkinin pozitif olduğunu tespit etmektedirler. Elde edilen sonuçlara göre GSYH büyüme oranı, nadiren kredi büyümesinin nedeni olmaktadır. Geleneksel nedensellik testi sonuçları ile GSYH büyüme oranından kredi büyümesine doğru herhangi bir nedensellik ilişkisi tespit edilemezken zamanla değişen nedensellik testi bu ilişkinin nadir de olsa bazı alt dönemlerde ortaya çıkabileceğini göstermektedir. Diğer yandan kredi genişlemesinin de GSYH büyüme oranının önemli nedenlerinden biri olduğu görülmektedir. Bu bulgu da beklentilere paraleldir ve geleneksel nedensellik testi tarafından da desteklenmektedir. Kredi büyümesi ise özellikle 20. dönemden sonra kalıcı bir biçimde neredeyse bugüne kadar GSYH büyümesinin nedeni olmaktadır. Bu dönemin başlangıcı 2008 finansal krizinin etkilerinin azaldığı 2011 yılının başına denk gelmektedir. Bu dönemde küresel olarak bollaşan likidite imkânları, Türkiye'de de kredi büyümesinin hızlanmasına yol açmış olabilir.

İkinci makro iktisadi değişkenimiz enflasyon oranıdır. Guo ve Stepanyan (2011) enflasyonun reel kredi büyümesi üzerindeki olumsuz etkilerinden bahsetmektedir. Kredi arzındaki azalma tüketim ve yatırım gibi toplam talebin ana bileşenlerinin yavaşlamasına yol açabilir. Enflasyonun ve oynaklığının yüksek olması bankaların varlık yönetimini zorlaştırarak kredi verme kararlarını olumsuz etkileyebilir. Diğer yandan yüksek ve belirsiz enflasyon ortamı yatırım ve tüketim kararlarını olumsuz etkileyerek kredi talebini yavaşlatabilir. Enflasyondan kredi büyümesine doğru nedensellik testi sonuçlarına göre enflasyon 16. dönemden 25. döneme kadar kredi büyümesinin nedenidir. Bu dönem 2009 yılının sonundan 2016 yılının sonuna kadarki zaman aralığını kapsamaktadır. Bu dönemler enflasyon oranlarının nispeten düşük ve istikrarlı olduğu dönemlerdir. Kredi büyümesi 2014 'ün sonundan günümüze kadarki süreçte enflasyonun nedeni olmaktadır. Geleneksel nedensellik testleri ise enflasyon ve kredi büyümesi arasında herhangi bir nedensellik ilişkisi tespit edememektedir. Makro iktisadi koşulları temsil eden son değişken kamu borcu değişkenidir. Bütçe açıkları ve kamu borçlanma ihtiyacındaki artışlar devlet tahvillerinin faizlerinin yükselmesine yol açacaktır. Bu durum bankaların krediler yerine devlet tahvillerinin varlıklar içindeki payını artırmasına ve dolayısıyla kamu borcunun kredi arzını dışlamasına neden olabilir. Ancak hem geleneksel nedensellik hem de zamanla değişen nedensellik testlerinden gelen bulgularımız kamu borcundan kredi büyümesine doğru sıkı bir nedensellik 
ilişkisi bulunamadığını göstermektedir. Tersine kredi büyümesinden kamu borcuna doğru nedensellik birçok alt dönemde karşımıza çıkmaktadır.

Grafik 2. Makro iktisadi Değişkenler ile Kredi büyümesi Arasındaki Zamanla Değişen Nedensellik Testi Sonuçları
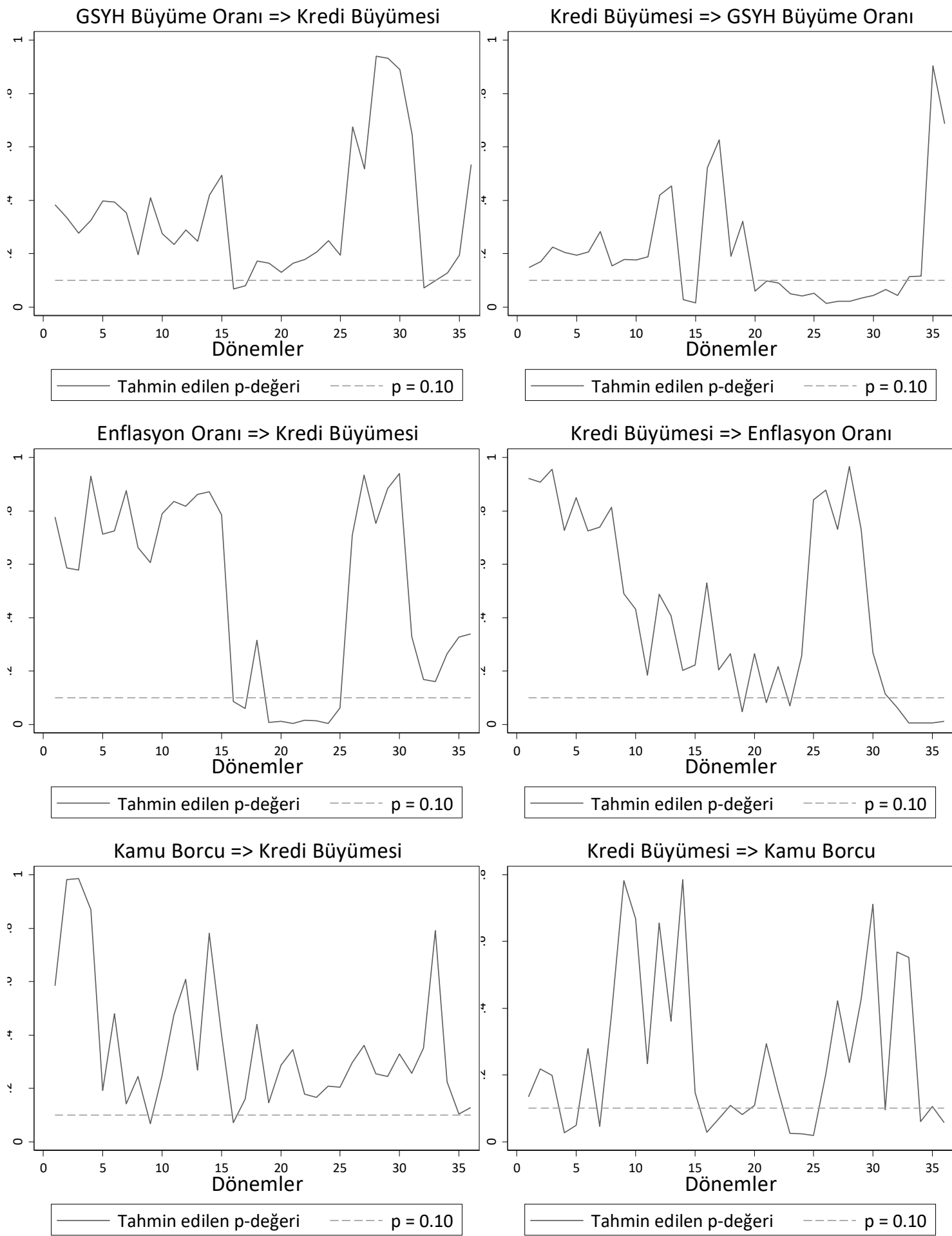
Kredi büyümesinin nedeni olabileceği düşünülen ikinci değişken grubu para politikası koşullarıdır. Para arzı koşulları merkez bankasının faizlerinin oluşmasını sağlarken merkez bankası faizleri ise bankaların likidite maliyetleri üzerinde belirleyici olabilmektedir. Akinlo ve Oni (2015) ve Awdeh (2017) para arzının krediler üzerindeki etkisinin pozitif olduğuna dair kanıtlar sunmaktadır. Her iki değişkenin de kredi büyümesinin nedeni olması muhtemeldir. Geleneksel nedensellik testi her iki değişkenden kredi büyümesine doğru bir nedensellik olduğunu göstermektedir. Zamanla değişen nedensellik testi sonuçlarına bakıldığında ise para arzından kredi büyümesine doğru nedensellik, TCMB faiz oranlarından kredi büyümesine doğru nedenselliğe göre daha belirsizdir. Para arzı ve faiz koşullarının her ikisi de ilgili alt dönemlerin başında ve sonunda açık bir biçimde kredi büyümesine neden olurken özellikle 2008 finansal krizi öncesinde TCMB faiz oranının kredi büyümesi ile ilişkisi para arzına göre daha belirgindir. Her iki değişken de 2014 yılının sonundan günümüze kadar kredi büyümesinin nedenidir. Kredi büyümesi ise özellikle 2010 yılının sonundan son bir yıla kadar para arzının nedeni iken aynı dönemlerde ortaya çıkmasına rağmen kredi büyümesinden TCMB faizlerine doğru nedensellik fazla belirgin değildir. Yine burada da geleneksel nedensellik testleri ile tespit edilemeyen nedensellik ilişkisi zamana bağlı olarak ortaya çıkabilmektedir. Merkez bankası faiz oranlarından kredilere doğru nedenselliğin elde edilmesi iki değişken arasında anlamlı ilişkiler olduğunu tespit eden Calza vd. (2003) çalışmasını da destekler niteliktedir. Kredi büyümesinden para arzına doğru nedenselliğin finansal sistemin daha fazla kullanıldığı dönemlerde ortaya çıkması muhtemeldir. Kredi arzındaki artışlar nakit sızıntısının az olduğu durumlarda tekrar bankacılık sistemine dönerek mevduat yaratılması sürecini hızlandıracak ve para arzının artmasına yol açacaktır. Diğer yandan aşırı kredi büyümesi fiyat istikrarını bozarak merkez bankasının faiz oranında değişiklik yapmasını uyarabilir.

Grafik 3. Para Politikası Duruşunu Değişkenleri ile Kredi büyümesi Arasındaki Zamanla Değişen Nedensellik Testi Sonuçları
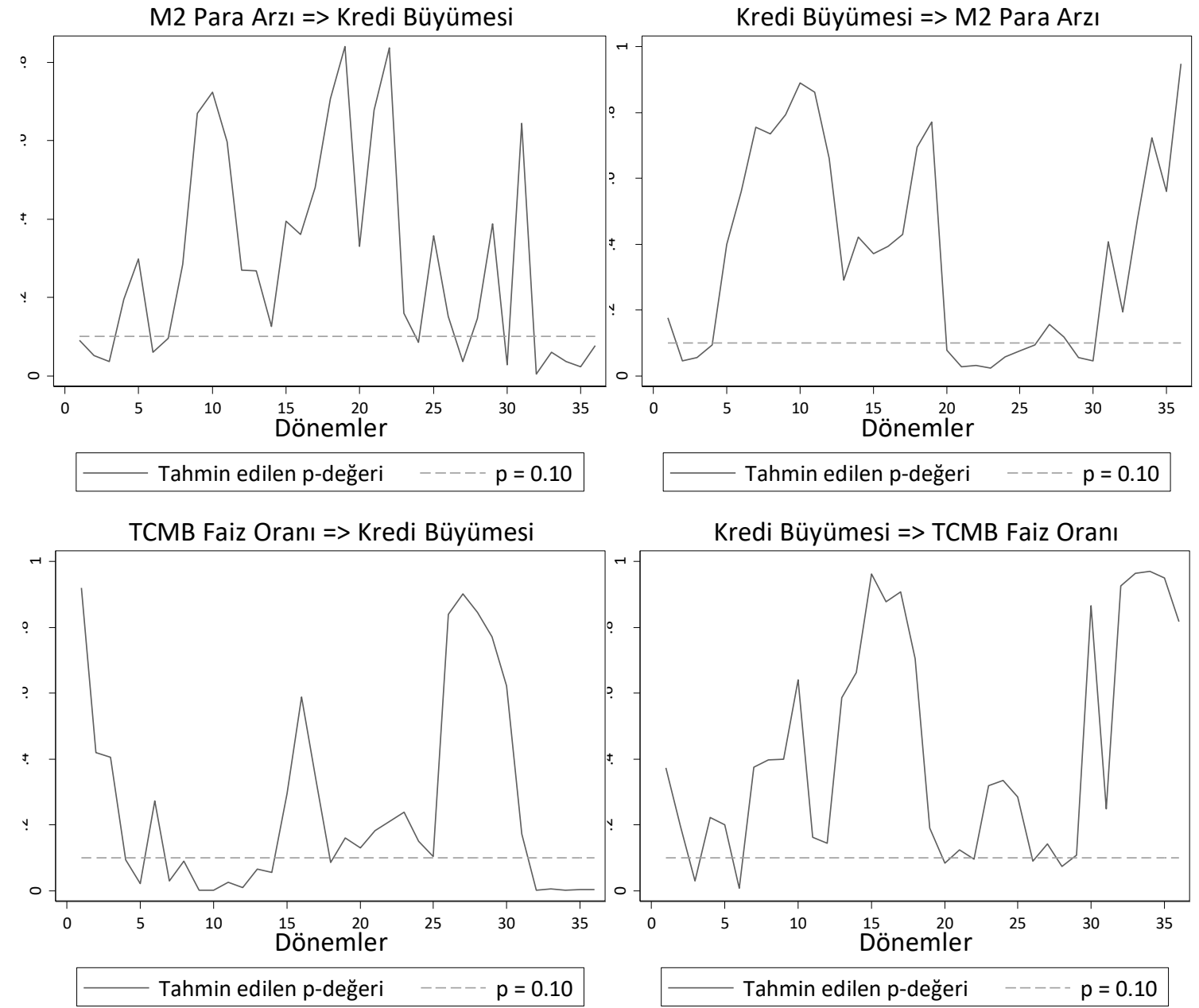
Kredi büyümesinin belirleyicileri olarak ele aldığımız üçüncü değişken grubu, dış talep ve küresel likidite koşullarının kredi büyümesi ile ilişkisini göstermek için analize dâhil edilmektedir. Bu değişkenlerin ilki $A B D$ federal fon oranıdır. ABD federal fon oranındaki azalışlar ya da ABD Merkez Bankası'nın parasal genişleme politikaları küresel olarak likiditeyi ucuzlatarak yerli bankaların daha düşük maliyetli yurtdışı kredi imkânlarına erişimine ve diğer finansal piyasalar aracılığıyla sermaye girişine yol açabilir. Bu koşullar kredi faizlerini düşürerek kredi hacminin artmasını sağlayabilir. Geleneksel nedensellik testlerinde iki değişken arasında bir ilişki ortaya çıkmamasına rağmen Federal fon oranının 2009 yılının başından 2015 yılının ortalarına kadar Türkiye'deki kredi büyümesinin nedeni olduğu tespit edilmektedir. Bu dönem ABD Merkez Bankası'nın 2008 finansal krizinin etkilerini ortadan kaldırabilmek için yüksek parasal genişleme ve düşük faiz oranı uyguladığı dönemlerdir. Bu tarihlerden sonra ise ABD Merkez Bankası kademeli bir biçimde parasal genişleme sürecini bitirerek faiz oranlarını yükseltmeye başlamıştır. Türkiye'deki kredi büyümesinden $A B D$ federal fon oranlarına doğru beklendiği gibi bir nedensellik tespit edilememektedir.

Küresel likidite koşullarını gösteren bir diğer değişken ise ülkeye giren portföy yatırımlarıdır. Sermaye girişlerinin $A B D$ federal fon oranına benzer bir şekilde kredi maliyetlerini düşürerek kredi büyümesini pozitif etkilemesi beklenmektedir. Aslında sermaye girişleri ABD faiz oranlarındaki düşüşler gibi gevşeyen küresel likidite koşullarının diğer ülkelere yansıdığı ikinci aşama olarak görülebilir. Geleneksel nedensellik testine paralel biçimde zamanla değişen nedensellik testi sonuçları da sermaye girişlerinin yoğun bir biçimde kredi büyümesine neden olduğunu göstermektedir. Tersine kredi büyümesinin yabancı sermaye girişini doğrudan tetiklemesi pek mantıklı değildir. Ancak kredi büyümesi ülkenin büyüme oranlarını etkileyerek ülkeye sermaye yatırımlarını özendirebilir. Hem geleneksel nedensellik hem de zamanla değişen nedensellik testinden elde edilen bulgular bu görüşü doğrular nitelikte değildir.

Grafik 4. Dış Talep ve Küresel Likidite Koşulları Değişkenleri ile Kredi büyümesi Arasındaki Zamanla Değişen Nedensellik Testi Sonuçları
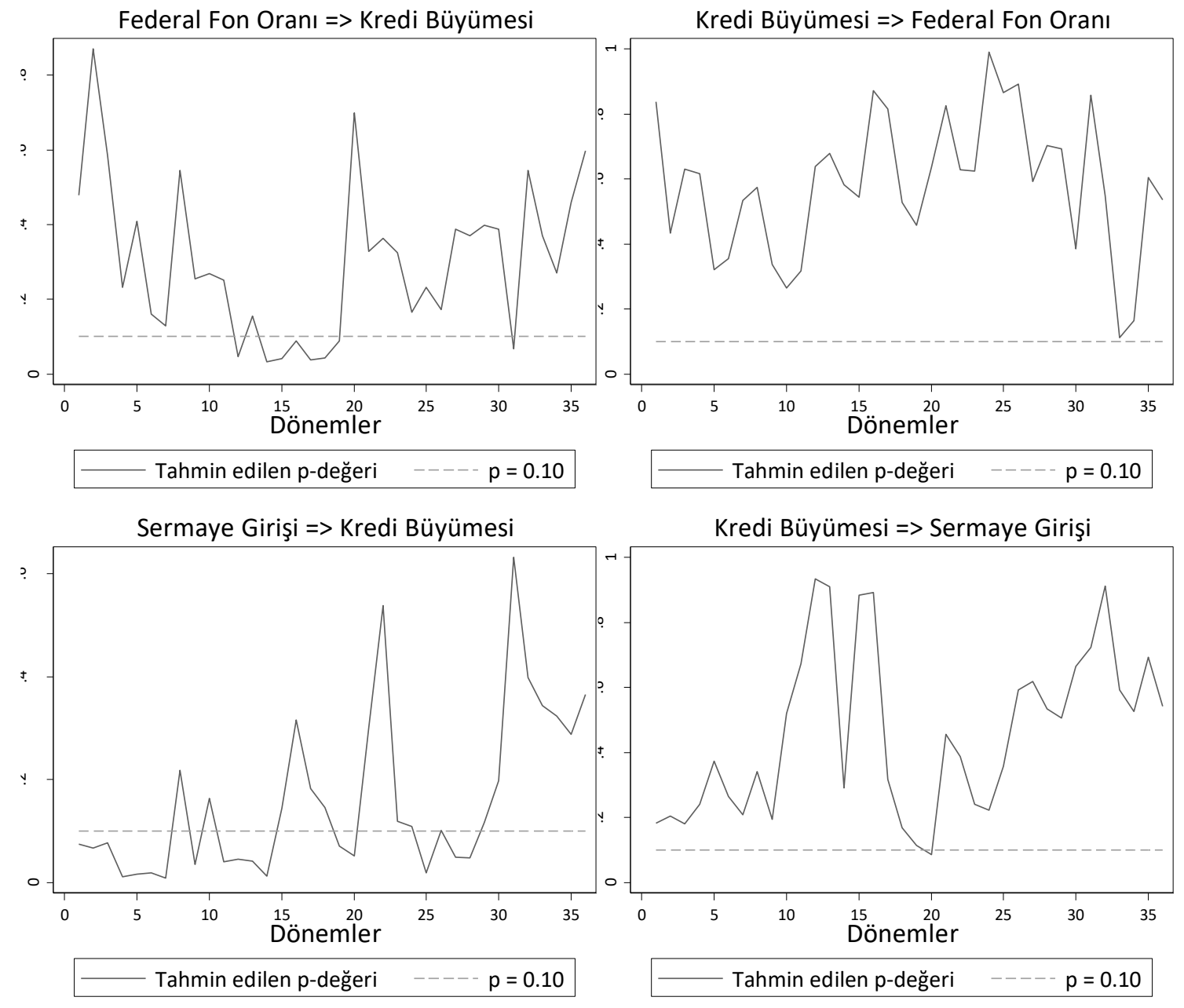
Grafik 4. Dış Talep ve Küresel Likidite Koşulları Değişkenleri ile Kredi büyümesi Arasındaki Zamanla Değişen Nedensellik Testi Sonuçları (Devamı)

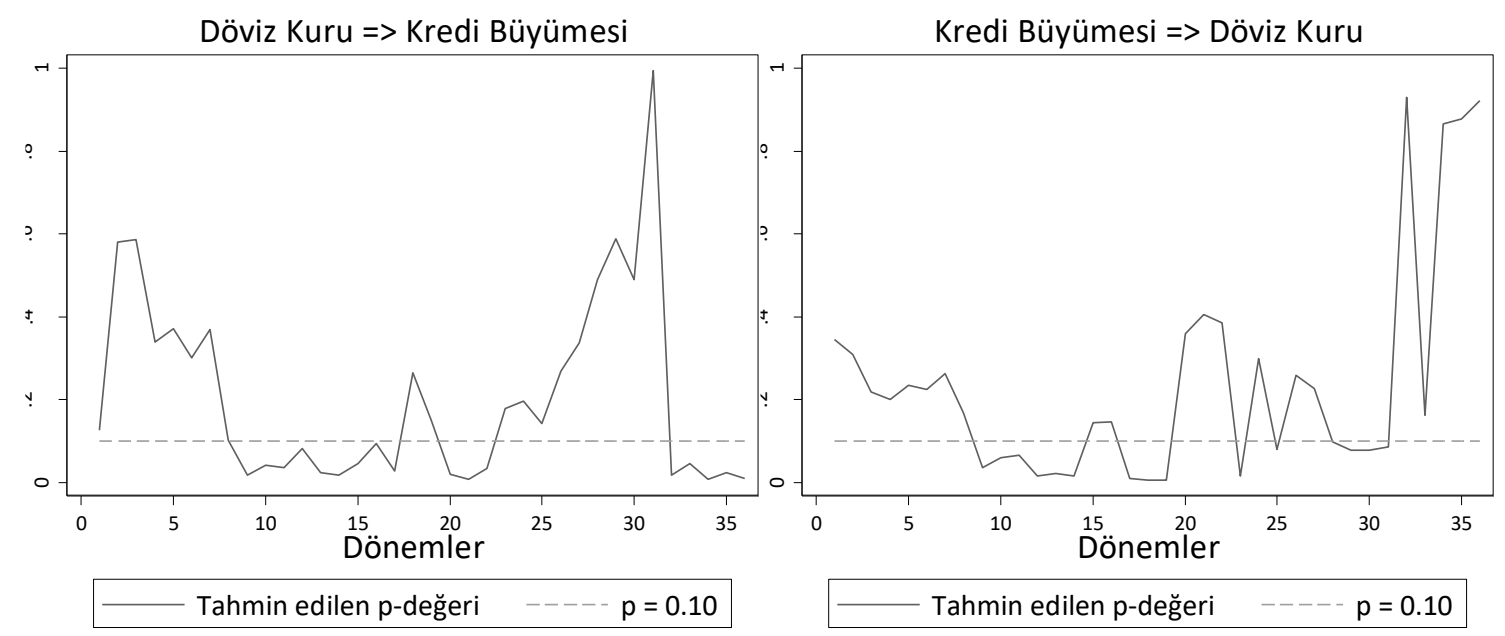

Döviz kurları ülkenin dış talep koşullarını etkileyen en önemli değişkenlerden biridir. Döviz kurundaki artışlar ihracat artışına yol açabilirken ithalatın azalmasını sağlayabilir. İhracattaki artışlar ise firmaların yatırımlarını artırmasını teşvik ederek kredi talebinin artmasına yol açabilir. Bu talebi karşılayabilecek kredi arzının mevcut olması durumunda ise kredi büyümesinin yaşanması oldukça muhtemeldir. Geleneksel nedensellik testinden elde edilen bulgular döviz kuru ve kredi büyümesi arasında iki yönlü nedenselliği doğrularken zamanla değişen nedensellik testi 2008 yılının başından 2016 yılının ortalarına kadar döviz kurunun kredi büyümesinin nedeni olduğunu göstermektedir. Kredi büyümesi ise enflasyonda bir artış yaratması durumunda enflasyon kanalı aracılığıyla yerli paranın değer kaybetmesine neden olabilir. Elde edilen bulgular bu önermeyi destekler niteliktedir ve birçok alt dönem için kredi büyümesinin döviz kurundaki değişimlerin nedeni olduğu gözlemlenmektedir.

Bankalara özgü bazı değişkenler kredi arzı ve farklı fon kaynaklarının maliyetini göstermesi bakımından kredi büyümesi üzerinde etkili olabilmektedir. İlk olarak kredilerin doğrudan maliyetini temsil eden kredi faizlerindeki azalışların kredi büyümesini artırması beklenmektedir (Akinlo ve Oni, 2015; Yiğitbaş, 2015; Awdeh, 2017). Kredi faizleri ile kredi büyümesi arasında geleneksel nedensellik testi çift yönlü nedensellik bulunduğunu göstermektedir. Ancak zamanla değişen nedensellik testi ile kredi faizlerinden kredi büyümesine doğru nedensellik ilişkisi yalnızca örneklemin ilk alt ve son alt dönemleri için tespit edilmektedir. Kredi büyümesinden kredi faizlerine doğru nedensellik de yine aynı dönemler için tespit edilmektedir. Geleneksel nedensellik testi yalnızca mevduat büyümesinden kredi büyümesine doğru bir nedensellik ilişkisi tespit etmektedir. Zamanla değişen nedensellik testinde ise mevduatlardaki büyümeden kredi büyümesine doğru da yine aynı dönemlerde nedensellik göze çarparken kredi büyümesinden mevduat büyümesine doğru nedensellik yalnızca son dönemlerde ortaya çıkmaktadır. Bu anlamda elde edilen nedensellik iliş̧isinin mevduatların krediler üzerinde anlamlı etkisi olduğunu ileri süren Sharma ve Gounder (2012), Ivanovic (2016), Awdeh (2017) ile uyumlu olduğu da söylenebilir. Mevduatlar bankaların en önemli fon kaynakları arasındadır. Mevduat hacmindeki yükselişler fon maliyetlerini azaltabilir ve bankaların daha fazla kredi verilebilecek kaynağa sahip olmasını sağlar. Diğer yandan kredilerdeki artış daha önce para arzı için bahsedilen mekanizma çerçevesinde mevduat artışına yol açabilecektir. Bankaların karlılık koşullarını temsil eden toplam varlıklarının karlılık oranı ve öz sermayenin karlılık oranı değişkenleri banka kredi büyümesi üzerinde etkiye sahip olabilir. Öz sermaye ve varlıkların karlılı̆ındaki yükselişler bankayı daha fazla kar elde edebilmek için kredileri artırmaya teşvik edebilir. Geleneksel nedensellik testinden elde edilen sonuçlar toplam varlıklarının karlılık oranı ile kredi büyümesi arasında çift yönlü bir ilişki bulunduğunu gösterirken öz sermaye karlılık oranından kredi büyümesine doğru yalnızca tek yönlü bir nedensellik bulunduğunu ortaya koymaktadır. Ancak zamanla değişen nedensellik testinde kredi büyümesinden bu değişkenlere doğru nedenselliğin tespit edildiği dönemler bu değişkenlerden kredi büyümesine doğru nedenselliğin tespit edildiği dönemlere göre daha yoğundur. Bu bulgu karlılık koşullarının diğer varlık türlerinden çok krediler tarafından yönlendirildiği şeklinde yorumlanabilir. 
Grafik 5. Bankalara Özgü Koşulları İçeren Değişkenler ile Kredi büyümesi Arasındaki Zamanla Değişen Nedensellik Testi Sonuçları
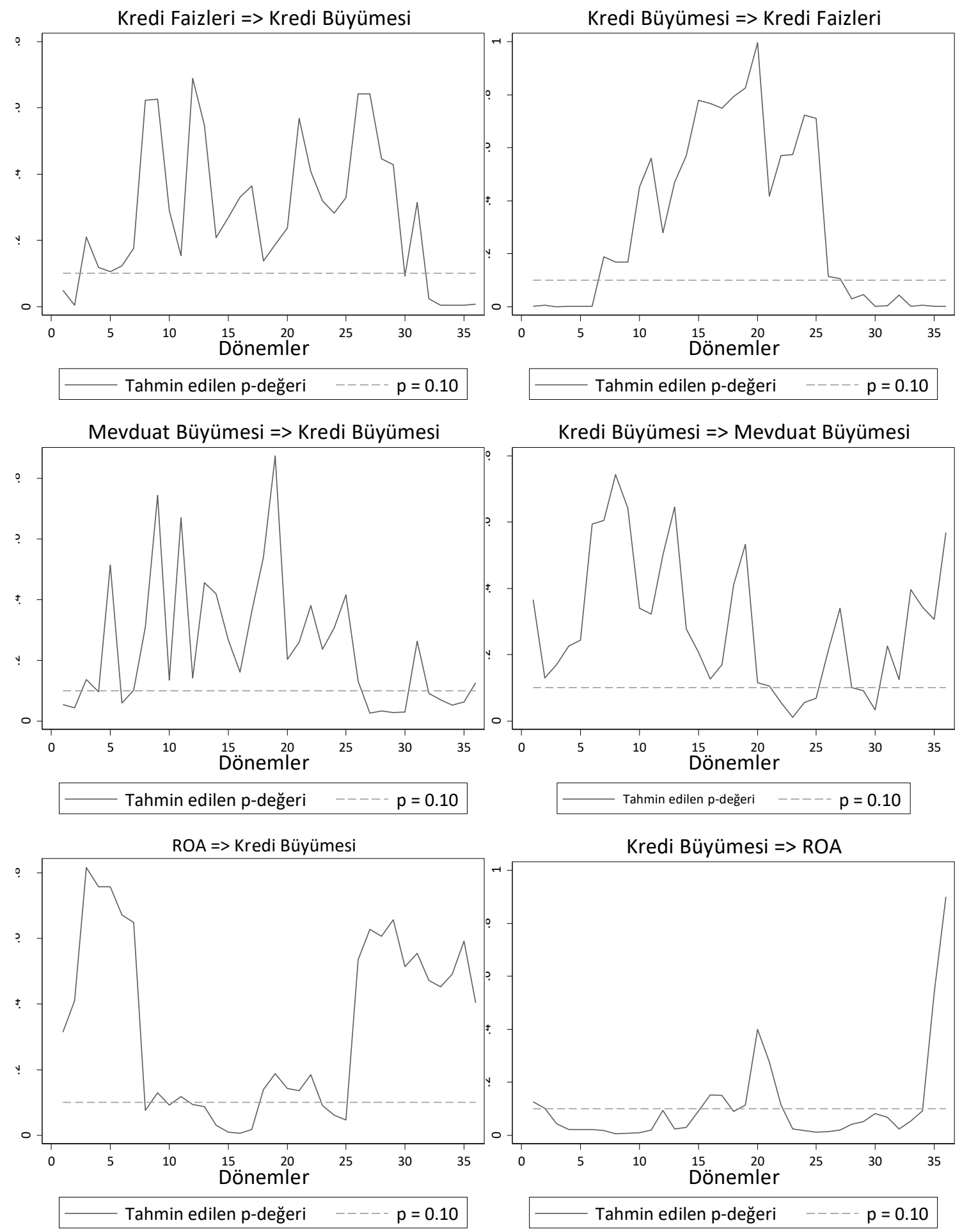
Grafik 5. Bankalara Özgü Koşulları İçeren Değişkenler ile Kredi büyümesi Arasındaki Zamanla Değişen Nedensellik Testi Sonuçları (Devamı)


\section{Sonuç}

Hızlı kredi büyümesinin yaşandığı dönemler hızlı büyüme dönemleriyle, bu dönemlerin sonu ise genellikle finansal ve makroekonomik istikrarsızlığın artmasıyla ilişkilendirilmektedir. Dolayısıyla banka kredileri politika yapıcılar tarafından gelecekte ekonominin durumu hakkında çıkarımlar yapabilmek için temel bir bilgi kaynağı olarak kullanılabilmektedir. Özellikle 2010 yılından son birkaç yıla kadar gelişmekte olan ülkelerde küresel likidite bolluğu ile birlikte yaşanan hızlı sermaye girişi kredi büyümesi üzerinde önemli etkiler yaratmıştır. Bu etkilerden Türkiye'de nasibini almıştır. 2010 yılı sonrasında hızı kredi genişlemesini yumuşatmak amacıyla verilen kredilerde vade sınırlandırması ve teminat oranlarının artırılması gibi makro ihtiyati tedbirlere başvurulmuştur. Bu tedbirler genellikle kredi genişlemesinin talep cephesine odaklanarak enflasyonist baskıları hafifletmeyi hedeflemiştir. Ancak diğer yandan bu politikalar meselenin arz cephesinden ele alınarak bankaların kredi maliyetlerini etkileyecek birçok değişken üzerinden de tasarlanabilmektedir. Dolayısıyla ekonomi üzerinde bu tür etkiler yaratabilen kredi büyüme değişkeninin belirleyicilerini tespit etmek de politika çıkarımları yapabilmek için oldukça önem arz etmektedir.

Bu çalışmada kredi büyümesi üzerinde etkili olabilecek banka yapısına ait bazı temel değişkenlerin yanı sıra para politikası koşulları, temel makro iktisadi değişkenler ve dış talep ve küresel likidite koşulları değişkenleri ile kredi büyümesi ilişkisi ampirik olarak incelenmektedir. Türkiye'nin 2006 ve 2019 dönemini kapsayan çeyreklik verileri ve zamana bağlı nedensellik testlerinden elde edilen bulgular, kredilerin temel makro iktisadi değişkenleri yönlendiren ana nedenlerden biri olduğu gerçeğini bir kez daha vurgularken; temel makro iktisadi değişkenlerden GSYH büyüme oranı ve enflasyonun kredi büyümesini yönlendiren faktörlerden biri olduğunu göstermektedir. Ancak kamu borcu için böyle bir ilişki daha seyrek olarak ortaya çıkmaktadır. Bunun yanı sıra para politikası duruşu da kredi büyümesinin ana nedenlerinden biri olarak değerlendirilmekte ve incelenmektedir. Parasal büyüklüklerin, para politikası faiz oranlarına göre daha zayıf bir ilişki gösterdiği sonucuna varılırken tersine kredi büyümesinin beklendiği gibi parasal büyüklüklerle daha belirgin bir ilişkisi bulunmaktadır. Diğer bir önemli sonuç ise kredi büyümesinin döviz kuru değişmeleri ve sermaye girişleri karşısında $A B D$ federal fon oranına göre daha hassas olduğudur. Kredi büyümesi ise muhtemelen enflasyonist etkileri aracılığıyla döviz kuru üzerinde etkili olmaktadır. Son olarak bankaların karlııı koşulları uzunca bir süre kredi büyümesini yönlendirirken bu ilişkinin son dönemlerde ortadan kalktığı görülmektedir. Ancak bu geçici bir dönem olabilir. Tersine kredi maliyetlerini gösteren mevduat büyümesi ve kredi faizleri ile kredi büyümesi arasındaki ilişkilerin ise son dönemlerde daha fazla belirginleştiği sonucuna varılmaktadır. Kredilerin ise banka karlılık oranlarının temel belirleyicisi olan varlık sınıflarından biri olduğu açıkça görülmekte ve bu sonuç Türk bankacılık sektörü için uzunca bir dönem geçerli olmaktadır. Bu sonuçlar kredi büyümesi ve belirleyicileri arasındaki ilişkinin zamana ve koşullara bağlı olarak sıklıkla değişebileceğini 
açıkça göstermektedir. Dahası kredi büyümesinin istikrarının makroekonomik ve finansal istikrar için son derece önemli olduğunu da açıkça göstermektedir. Kredi büyümesinin daha istikrarlı bir şekilde yönlendirilebilmesi için daha fazla bankalara özgü değişkenin krediler üzerindeki etkilerinin belirlenmesine ihtiyaç duyulmaktadır. Bu durumda daha etkin, hassas ve esnek politika tasarımlarının yapılabilmesi daha muhtemeldir. Dolayısıyla gelecek çalışmalar, Türkiye'de bankalara özgü koşulların kredi hacmi üzerindeki etkilerinin daha kapsamlı araştırılması üzerine tasarlanabilir.

\section{Beyan ve Açıklamalar (Disclosure Statements)}

1. Bu çalışmanın yazarları, araştırma ve yayın etiği ilkelerine uyduklarını kabul etmektedirler (The authors of this article confirm that their work complies with the principles of research and publication ethics).

2. Yazarlar tarafından herhangi bir çıkar çatışması beyan edilmemiştir (No potential conflict of interest was reported by the authors).

3. Bu çalışma, intihal tarama programı kullanılarak intihal taramasından geçirilmiştir (This article was screened for potential plagiarism using a plagiarism screening program).

\section{Son Notlar}

1. GSYH büyüme oranı, kamu borcu ve öz sermaye getiri oranı serilerinin düzey değerleri ve ABD Federal Fon Oranı serisinin birinci fark değeri için ilave olarak Kwiatkowski-Phillips-Schmidt-Shin (KPSS) testi uygulanmış ve kamu borcunun düzeyde durağan olduğu, diğer değiskenlerin ise durağan olmadıkları ve I(1) düzeyinde durağan hale geldikleri tespit edilmektedir. Dolayısıyla bu seriler ile kredi büyümesi ilişkisi modellenirken Toda ve Yamamoto (1995) ve Dolado ve Lütkepohl (1996) tarafindan önerilen genişletilmiş VAR $(p+d)$ süreci takip edilmekte ve $d=1$ olarak alınmaktadır. I(O) olan seriler arasında kurulan modellerde ise $d=0$ olarak alınmaktadır. Kurulan VAR modellerinin optimal gecikme uzunluğu Akaike Bilgi Kriteri tarafından belirlenmektedir.

\section{Kaynaklar}

Akinlo, A. E., \& Oni, I. O. (2015). Determinants of bank credit growth in Nigeria 1980-2010. European Journal of Sustainable Development, 4(1), 23-23.

Alessi, L., \& Detken, C. (2014). Identifying excessive credit growth and leverage. ECB Working Paper No. 1723, European Central Bank.

Alihodžić, A., \& Ekşi, i. H. (2018). Credit growth and non-performing loans: evidence from Turkey and some Balkan countries. Eastern Journal of European Studies, 9(2), 229-249.

Awdeh, A. (2017). The determinants of credit growth in Lebanon. International Business Research, 10(2), 9-19.

Balcilar, M., Ozdemir, Z. A., \& Arslanturk, Y. (2010). Economic growth and energy consumption causal nexus viewed through a bootstrap rolling window. Energy Economics, 32(6), 1398-1410.

Beck, T., Levine, R., \& Loayza, N. (2000). Finance and the sources of growth. Journal of Financial Economics 58, 261-300.

Bernanke, B., \& Gertler, M. (1995). Inside the black box: The credit channel of monetary policy transmission. NBER Working Paper No. 5146.

Borio, C., \& Drehmann, M. (2009). Assessing the risk of banking crises - revisited. BIS Quarterly Review, 29-46.

Borio, C., Furfine C., \& Lowe, P. (2002). Procyclicality of the financial system and financial stability: Issue and policy options. BIS Working Papers 1, 1-57.

Calza, A., Gartner, C., \& Sousa, J. (2003). Modelling the demand for loans to the private sector in the Euro area. Applied Economics, 35(1), 107-117.

Chen, G., \& Wu, Y. (2014). Bank ownership and credit growth in emerging markets during and after the 2008- 09 financial crisis: A cross-regional comparison. IMF Working Paper WP/14/171, International Monetary Fund, Washington D.C. 
Cucinelli, D. (2015). The impact of non-performing Loans on bank lending behavior: Evidence from the Italian banking sector. Eurasian Journal of Business and Economics, 8, 59-71.

Dolado, J. J., \& Lütkepohl, H. (1996). Making Wald tests work for cointegrated VAR systems. Econometric Reviews, 15(4), 369-386.

Elekdag, S., \& Wu, Y. (2011). Rapid credit growth: Boon or boom-bust? In IMF Working Paper 11/241. Washington: International Monetary Fund.

Elekdag, S., \& Han, F. (2015). What drives credit growth in emerging Asia? Journal of Asian Economics, 38, 1-13.

Friedman, B., \& Kuttner, K. (1993). Economic activity and the short-term credit markets: An analysis of prices and quantities. Brookings Papers on Economic Activity, 2, 193-283.

Gourinchas, P. O., \& Obstfeld, M. (2012). Stories of the twentieth century for the twenty-first. American Economic Journal: Macroeconomics, 4(1), 226-65.

Gözgör, G. (2014). Determinants of domestic credit levels in emerging markets: The role of external factors. Emerging Markets Review, 18, 1-18.

Guo, K., \& Stepanyan, V. (2011). Determinants of bank credit in emerging market economies. IMF Working Paper WP/11/51, International Monetary Fund, Washington D.C.

Hacker, R. S., \& Hatemi-J, A. (2006). Tests for causality between integrated variables using asymptotic and bootstrap distributions: Theory and application. Applied Economics, 38(13), 1489-1500.

Igan, D., \& Pinheiro, M. (2011). Credit growth and bank soundness: Fast and furious? IMF Working Paper WP/11/278, International Monetary Fund, Washington D.C.

Imran, K., \& Nishat, M. (2013). Determinants of bank credit in Pakistan: A supply side approach. Economic Modelling, 35, 384-390.

Ivanović, M. (2016). Determinants of credit growth: The case of Montenegro. Journal of Central Banking Theory and Practice, 5(2), 101-118.

Kashyap, A., Stein, J., \& Wilcox, D. (1993). Monetary policy and credit conditions: Evidence from the composition of external finance. American Economic Review, 83, 8-98.

Levine, R. (2005). Finance and growth: Theory and evidence. Handbook of Economic Growth, 1, 865-934.

Love, I. (2003). Financial development and financing constraints: International evidence from the structural investment model. The Review of Financial Studies, 16(3), 765-791.

Mendoza, E., \& Terrones, M. (2008). An anatomy of credit booms: Evidence from macro aggregates and micro data. In NBER Working Paper No. 14049. Cambridge, Massachusetts: National Bureau of Economic Research.

Obstfeld, M., \& Rogoff, K.S. (2010). Global imbalances and the financial crisis: Products of common causes. In: Glick, R., Spiegel, M. M. (Eds.), Asia and the Global Financial Crisis, Federal Reserve Bank of San Francisco, San Francisco.

Phillips, P. C. B., \& Perron, P. (1988). Testing for a unit root in time series regression. Biometrika, 75(2), 335-346.

Sharma, P., \& Gounder, N. (2012). Determinants of bank credit in small open economies: The case of six Pacific Island Countries. Available at SSRN 2187772.

Shijaku, G., \& Kalluci, I. (2013). Determinants of bank credit to the private sector: The case of Albania. Bank of Albania Working paper, No. 09(48).

Tan, M. T. B. P. (2012). Determinants of credit growth and interest margins in the Philippines and Asia. International Monetary Fund (No. 12-123).

Toda, H. Y., \& Yamamoto, T. (1995). Statistical inference in vector autoregressions with possibly integrated processes. Journal of Econometrics, 66(1-2), 225-250.

Thaker, H. M. T., Ee, T. S., Sin, C. F., \& Man, W. H. (2013). The macroeconomic determinants of bank credit in Malaysia: An analysis via the error correction model (ECM). Skyline Business Journal, 9(1), 1-9.

Tomak, S. (2013). Determinants of commercial banks' lending behavior: Evidence from Turkey. Asian Journal of Empirical Research, 3(8), 933-943.

Wurgler, J. (2000). Financial markets and the allocation of capital. Journal of Financial Economics, 58 (1-2), $187-214$.

Yiğitbaş, Ş. B. (2015). Türkiye'de özel işletme kredilerinin belirleyicileri. Akademik Bakış Uluslararası Hakemli Sosyal Bilimler Dergisi, (47), 287-297. 